\title{
De nuevo sobre los concejales no adscritos (a propósito de la sentencia del tribunal constitucional 151/2017, de 21 de diciembre $)^{1}$
}

\author{
Again on non-attached members of local government \\ (the ruling of the constitutional court 151/2017, december 21)
}

\author{
Lourdes de la Torre Martínez \\ Universidad de Jaén \\ lotorre@ujaen.es
}

\begin{abstract}
NOTA BIOGRÁFICA
Profesora Contratada Doctora desde septiembre de 2005 y acreditada por ANECA como Profesor Titular de Universidad desde junio de 2013. Cuenta con dos sexenios de investigación reconocidos por la CNEAI (2005-2010) y (2011-2016). Se licencia en Derecho por la Universidad de Jaén en junio de 2000 (número uno de la promoción 1996-2000, con varios premios) y en abril de 2001 obtiene una beca FPU del MECD. Presenta DOCTORADO EUROPEO, bajo el título Telecomunicaciones y Municipios, dirigida por el profesor Jiménez-Blanco Carrillo de Albornoz, realizando estancias de investigación de larga duración en las Universidades alemanes de Colonia y Bochum. Sus líneas de investigación principales son: Derecho de las Telecomunicaciones, Derecho Local y Servicios de Interés Económico General en Europa, que ha desarrollado en un grupo de investigación financiado por la Comunidad Autónoma de Andalucía (Andalucía y la Unión Europea. Participación institucional de la Comunidad Autónoma Andaluza en el proceso de desarrollo de la Unión Europea) y varios proyectos de investigación: uno, I+D+i del Plan Nacional del Ministerio de Ciencia e Innovación (Los intereses colectivos: representación y defensa ante la Administración y los tribunales. Las «otras» legitimaciones), otro, del que ha sido IP, de la Universidad de Jaén (El impacto de la LO 3/2007 para la igualdad efectiva entre mujeres y hombres en el Derecho administrativo con carácter general y en el acceso a la Jurisdicción Contencioso-Administrativa en particular). En la actualidad es IP del Proyecto $1+\mathrm{D}+\mathrm{i}$ del Plan Nacional Las entidades locales, sus relaciones y competencias. Realidad, efectos y consecuencias de la racionalización y sostenibilidad financiera en Andalucía (DER2016-74843C3-3-R), que se enmarca en otro principal, dirigido por la profesora Carbonell Porras. Ha sido responsable de 5 proyectos de innovación docente financiados por la Universidad de Jaén desde el año 2005 hasta la actualidad. Ha desempeñado distintos cargos unipersonales en la Universidad de Jaén, en el Decanato de la Facultad de Ciencias Sociales y Jurídicas, desde febrero de 2006 hasta 2014. Desde mayo 2015 es Vicesecretaria General.
\end{abstract}

\section{RESUMEN}

En este trabajo analizamos la Sentencia del TC 151/2017, que da un paso adelante en la configuración de los derechos que corresponden a los concejales no adscritos, inherentes al art. 23.2 CE. En particular,

\footnotetext{
1 Este trabajo se realiza en el marco del Proyecto I+D+i del Plan Nacional, Las Entidades locales, sus relaciones y competencias. Realidad, efectos y consecuencias de la racionalización y sostenibilidad financiera en clave nacional y europea (DER2016-74843C3-1-R), del que la Investigadora Principal es Eloísa Carbonell Porras. A su vez, se integra en el proyecto subordinado Las entidades locales, sus relaciones y competencias. Realidad, efectos y consecuencias de la racionalización y sostenibilidad financiera en Andalucía (DER2016-74843-C3-3-R), del que soy investigadora principal. Ambos se desarrollan en el Grupo de Investigación del Plan Andaluz de Investigación, Desarrollo e Innovación (PAIDI) SEJ-317, "El Derecho Público y la crisis institucional y económica".
} 
nos referimos al derecho a la participación en la actividad de control del gobierno local cuando se trata de presentar una moción de censura contra el Alcalde. En la Sentencia, el TC reconoce la aplicación del citado derecho a todos los concejales, eliminando el quorum reforzado exigido por el art. 197.1 letra a) párrafo 3 LOREG a los concejales no adscritos, sin diferenciar las circunstancias ni los objetivos, no necesariamente fraudulentos, que pudieron llevar a esa desvinculación y declarando su nulidad.

\title{
PALABRAS CLAVE
}

Concejales no adscritos; transfuguismo; moción de censura; derecho fundamental del artículo 23.2 CE.

\begin{abstract}
In this work we study the ruling of the Constitutional Court 151/2017 that implies a step forward in the setting of the rights regarding non-attached members of the Local Government (art. 23.2 CE). In particular we refer to the participation in the control of the Local Government when dealing with a motion of censure against the Mayor. In this sense, the Constitutional Court recognizes this right to all the members of the Local Government, and eliminates the requirement of reinforced quorum in art.197.1 letter a, paragraph 3 LOREG for non-attached members, without differentiating neither the circumstances nor the not necessarily fraudulent goals, that could have led to that decoupling, declaring it null.
\end{abstract}

\section{KEYWORDS}

Non-attached members; political defection; motion of censure; fundamental right of art. $23.2 \mathrm{CE}$

\section{SUMARIO}

I. INTRODUCCIÓN. II. ESTADO DE LA CUESTIÓN. III. LA SENTENCIA DEL TRIBUNAL CONSTITUCIONAL 151/2017, DE 21 DE DICIEMBRE: 1. ANTECEDENTES DE HECHO. 1.1. La Sentencia del Juzgado de lo Contencioso-Administrativo de Santa Cruz de Tenerife. 1.2. El recurso de apelación ante el TSJ de Canarias y planteamiento de la cuestión de inconstitucionalidad con relación al artículo 197.1 a) LOREG, párrafo tercero, por vulneración del artículo 23.2 CE. 1.3. Las alegaciones de las partes. 2. LA FUNDAMENTACIÓN DE LA SENTENCIA. 2.1. La participación en la actividad de control del gobierno local es una función de todos los concejales y pertenece al núcleo representativo del art. 23.2 CE. 2.2. Análisis de la constitucionalidad del art. 197.1 a) párrafo tercero LOREG. 2.3. Juicio de idoneidad, de necesidad y de proporcionalidad en sentido estricto del artículo art. 197.1 a) párrafo tercero LOREG. 2.4. Alcance y efectos del fallo. 3. VOTOS PARTICULARES. IV. REFLEXIONES FINALES. V. BIBLIOGRAFÍA.

\section{INTRODUCCIÓN}

El abandono de los concejales de su grupo político de procedencia y el transfuguismo no son fenómenos nuevos, sino que vienen generando bastantes problemas en el ámbito político y jurídico desde hace tiempo ${ }^{2}$, de ahí que el Tribunal Constitucional (en lo sucesivo TC) desde la década de los ochenta ha intentado resolver diversas cuestiones relativas a la titularidad del cargo cuando el concejal abandona su parti$\mathrm{do}^{3}$. La mayoría de la doctrina considera que esta práctica anómala en la vida local cuenta con importantes

2 La figura del concejal no adscrito procede del Acuerdo sobre un Código de Conducta Política en relación con el Transfuguismo en las Corporaciones Locales suscrito entre el Ministerio de Administraciones Públicas y los representantes de todos los partidos políticos del Parlamento, de 7 de julio de 1998, conocido también como «Acuerdo Antitránsfuga». El Acuerdo de 1998 ha sido renovado en dos ocasiones, en el año 2000 y por la II Adenda, de 23 de mayo de 2006. Según la II Adenda, tránsfugas son: «los representantes locales que, traicionando a sus compañeros de lista y/o de grupo -manteniendo estos últimos su lealtad con la formación política que los presentó en las correspondientes elecciones locales-, o apartándose individualmente o en grupo del criterio fijado por los órganos competentes de las formaciones políticas que los han presentado, o habiendo sido expulsados de éstas, pactan con otras fuerzas para cambiar o mantener la mayoría gobernante en una entidad local, o bien dificultan o hacen imposible a dicha mayoría el gobierno de la entidad».

3 Una de las primeras Sentencias del TC en esta materia, la STC 10/1983, de 21 de febrero, desarrolla el contenido del derecho al cargo público y reconoce que: «una vez elegidos, los representantes no lo son de quienes los votaron, sino de todo el cuerpo electoral, y titulares, por tanto, de una función pública a la que no pueden poner término decisiones de entidades que no son órganos del Estado, en el sentido más amplio del término». 
REALA. Nueva Época - N. 9, Abril 2018 - ISSN: 1989-8975 - DOI: 10.24965/reala.v0i9.10511 - [Págs. 110-127]

De nuevo sobre los concejales no adscritos(a propósito de la sentencia del tribunal constitucional 151/2017, de 21 de diciembre)

consecuencias ${ }^{4}$. Además, no podemos perder de vista que a la luz de la regulación vigente la figura del tránsfuga no siempre coincide con la del concejal no adscrito ${ }^{5}$. De este modo, la calificación de concejal no adscrito implica un régimen jurídico definido en la legislación básica estatal, en la autonómica, y en la normativa de los Municipios, que no tiene por qué coincidir con la de concejal tránsfuga. No se trata, por tanto, de nociones recíprocas ${ }^{6}$.

En este trabajo tratamos principalmente de dar cuenta de la Sentencia del TC 151/2017, de 21 de diciembre, en la que el Tribunal da un nuevo paso adelante en la configuración de los derechos de los concejales no adscritos, derivados del núcleo fundamental y representativo del art. $23.2 \mathrm{CE}$. En particular, nos referimos al derecho que corresponde a los concejales de participación en la actividad de control del gobierno local. En este supuesto el TC declara, de forma expresa y por vez primera, que la ruptura de un concejal con su partido político no siempre tiene naturaleza fraudulenta. EI TC trata de dilucidar si los concejales no adscritos ven limitado su derecho a participar en la actividad de control del gobierno local, cuando promueven una moción de censura del Alcalde al amparo del art. 197.1 letra a) párrafo tercero de la Ley Orgánica de Régimen Electoral General, la Ley Orgánica 2/2011, de 28 de enero, por la que se modifica la Ley Orgánica de Régimen Electoral General de 1999 (en adelante LOREG). Además, el TC analiza si el citado derecho constituye un derecho fundamental incardinado en el art. 23.2 CE.

Finalmente, el TC, en la Sentencia objeto de estudio, concluye con la declaración de inconstitucionalidad del art. 197.1 letra a) párrafo tercero de la LOREG.

\section{ESTADO DE LA CUESTIÓN}

Antes de adentrarnos en el estudio de la Sentencia del TC 151/2017, de 21 de diciembre, resulta imprescindible conocer el contexto en el que surge la figura de los concejales no adscritos, su régimen jurídico y su relación con el concepto político de transfuguismo.

El punto de partida debemos situarlo en el art. 73 de la Ley $7 / 1985$, de 2 de abril, Reguladora de las Bases de Régimen Local (en adelante LBRL). En la redacción original del art. 73 LBRL no contemplaba ninguna previsión respecto a los concejales no adscritos ni a los grupos políticos, y permitía, en cierto modo, la equiparación de los derechos de éstos con los que corresponden a los concejales en general. El Real Decreto 2568/1986, de 28 de noviembre, por el que se aprueba el Reglamento de organización, funcionamiento y régimen jurídico de las Entidades locales (en los sucesivo ROF) contiene la regulación aplicable a los grupos políticos en los artículos 23 a 29 y establece que los miembros de las Corporaciones Locales, a efectos de su actuación corporativa, se constituirán en grupos y que nadie puede pertenecer simultáneamente a más de un grupo (art. 23).

La figura del concejal no adscrito nace en el seno de un acuerdo político, el Acuerdo sobre un Código de Conducta Política en relación con el Transfuguismo en las Corporaciones Locales suscrito entre el Ministerio de Administraciones Públicas y los representantes de todos los partidos políticos del Parlamento, de 7 de julio de 1998, también conocido como «Acuerdo Antitránsfuga» ${ }^{7}$. Además se crea

${ }^{4}$ DE ESTEBAN, J. (1990), "El fenómeno del transfuguismo político y la jurisprudencia constitucional”, REP, núm. 70, págs. 7-32; MURILLO DE LA CUEVA, P. L. (1992), "Problemas constitucionales de la representación política”, Debate Abierto, núm. 7, pág. 142 y ss.; ABELLAN, A. M. (1994), "Los representantes y el derecho de participación en el ordenamiento jurídico español", REP, núm. 84, pág. 212 y ss.; PRESNO LINERA, M. A. (1998), "La superación del transfuguismo político en las corporaciones locales como exigencia de una representatividad democrática", REALA, núm. 277, pág. 120; GARCíA ROCA, J. (1998), Cargos públicos representativos. Un estudio del art. 23.2 de la Constitución, Aranzadi, pág. 79; GONZÁLEZ DEL TESO, T. (2005), "Transfuguismo y concejales no adscritos (A propósito de la reforma de la LBRL por la Ley 57/2003)", Justicia Administrativa, núm. 27, pág. 38. No obstante, hay autores en nuestra doctrina que defienden como respuesta al transfuguismo la pérdida del cargo: BLANCO VALDÉS, R. L. (1990), Los partidos políticos, Madrid, Tecnos, pág. 55; BLANCO VALDÉS, R. L. (2003), "Transfuguismo y democracia en la Comunidad de Madrid", Claves de la Razón Práctica, núm. 135, pág. 47.

5 ALONSO MÁS, M. J. (2005), "El discutible régimen jurídico de los concejales no adscritos", Revista de Administración Pública, núm. 168, septiembre-diciembre, págs. 98 a 107.

${ }^{6}$ La condición de concejal tránsfuga implica una calificación política otorgada por la Comisión de Seguimiento con fundamento en el Pacto Antitránsfuga de 2006 y conlleva la adopción de ciertas medidas que vienen a castigar al concejal tránsfuga, previstas de cara a las futuras elecciones.

7 Una de las reglas que introdujo el Acuerdo consistía en «desincentivar el transfuguismo político a través de la adopción de medidas disuasorias de carácter económico, reglamentario y protocolario», y propiciar las reformas en los reglamentos orgánicos de las Corporaciones locales con el fin de fijar que "los concejales que abandonen los partidos o agrupaciones en cuyas candidaturas resultaron elegidos no pasen al Grupo Mixto, sino que se organicen a partir de la creación de la figura de los «No Inscritos» o del «Concejal 
REALA. Nueva Época - N. 9, Abril 2018 - ISSN: 1989-8975 - DOI: 10.24965/reala.v0i9.10511 - [Págs. 110-127]

De nuevo sobre los concejales no adscritos(a propósito de la sentencia del tribunal constitucional 151/2017, de 21 de diciembre)

Lourdes de la Torre Martínez

una Comisión de Seguimiento del Pacto Antitransfuguismo desde $1998^{8}$. El Acuerdo de $1998^{9}$ ha sido renovado en dos ocasiones, en el año 2000 y por la II Adenda de 23 de mayo de 2006, con el fin principal de eliminar los efectos perversos de la práctica del transfuguismo y la adopción en el futuro de reglas que lo obstaculicen ${ }^{10}$.

La Ley 11/1999, de 21 de abril, de modificación de la Ley Reguladora de las Bases del Régimen Local (en adelante Ley 11/1999) ${ }^{11}$ introduce el apartado 3 del art. 73 e incorpora el derecho-deber de los concejales a constituirse en grupos políticos, en la forma y con los derechos y las obligaciones que se establezcan ${ }^{12}$. Este reforzamiento de los grupos políticos se pone también de manifiesto, de un lado, con la reforma del art. 46 que hace la LBRL con la Ley 11/1999, garantizando su presencia efectiva en la parte de los Plenos dedicada al control de los órganos de gobierno y, de otro lado y en lo que ahora nos interesa al objeto de nuestro estudio, con la modificación del art. 197 de la LOREG, mediante la Ley Orgánica 8/1999, de 21 de abril (en la actualidad la Ley Orgánica 2/2011, de 28 de enero, por la que se modifica la Ley Orgánica de Régimen Electoral General de 1999) que reconoce a los miembros de la Corporación local el derecho que les corresponde a participar en las sesiones donde se debata una moción de censura ${ }^{13}$. En particular, es preciso detenernos en el contenido del artículo 197. 1 letra a), tercer apartado, LOREG, por cuanto es objeto de estudio posterior con la Sentencia:

«1. El Alcalde puede ser destituido mediante moción de censura, cuya presentación, tramitación y votación se regirá por las siguientes normas:

a) La moción de censura deberá ser propuesta, al menos, por la mayoría absoluta del número legal de miembros de la Corporación y habrá de incluir un candidato a la Alcaldía, pudiendo serlo cualquier Concejal cuya aceptación expresa conste en el escrito de proposición de la moción.

En el caso de que alguno de los proponentes de la moción de censura formara o haya formado parte del grupo político municipal al que pertenece el Alcalde cuya censura se propone, la mayoría exigida en el párrafo anterior se verá incrementada en el mismo número de concejales que se encuentren en tales circunstancias.

\footnotetext{
Independiente», con la concreción en su caso, del correspondiente grupo de «no inscritos» y actúen en la Corporación de forma aislada, sin que puedan percibir o beneficiarse de los recursos económicos y materiales a disposición de los grupos políticos de la Corporación".

8 La Comisión de Seguimiento del Pacto Antitransfuguismo desde 1998 está integrada por cada uno de los partidos políticos firmantes y por el Ministerio de Administraciones Públicas, presidida por el Ministro de Administraciones Públicas, como órgano encargado del control y del seguimiento del cumplimiento de los citados Acuerdos.

9 El Código de Conducta pretende eliminar los efectos perversos de esta práctica y destacamos la regla segunda que se adopta: "Los partidos políticos que suscriben los Acuerdos de comprometen a rechazar y no admitir en su grupo político a un concejal integrado en la candidatura de otra formación, mientras mantenga el cargo conseguido en su partido original. Asimismo se comprometen a no favorecer ni beneficiarse de los efectos del transfuguismo cuando el trasvase se produzca hacia un grupo político no firmante de este Acuerdo». Puede consultarse las actividades realizadas por la Comisión de Seguimiento en la página web www.seap.minhap.gob.es.

10 En la doctrina: Informe sobre el gobierno local, MAP, Madrid, 1992, págs. 305, 307 y 320; VANDELLI, L. (1997), "Tendencias del Derecho Administrativo en Italia", Documentación Administrativa, núms. 248-249, pág. 15; El desarrollo del gobierno local (una aproximación doctrinal), serie Administración General, Colección Informes y Documentación, Madrid, 1999, pág. 30; VANACLOCHA BELVER, F. J. (1999), "Los fenómenos del transfuguismo en la nueva política local”, El desarrollo del gobierno local (una aproximación doctrinal), serie Administración General, Colección Informes y Documentación, Madrid, pág. 199 y ss; El pacto local. Medidas para el desarrollo del gobierno local, MAP y FEMP, 1999, pág. 102 y ss; CAPO GIOL, J. (1999), "El debate sobre el sistema electoral. Imágenes, intereses y propuestas", en Elecciones locales, Madrid, INAP, págs. 143 a 213; NIETO-GUERRERO, A. M. (2001), Los Entes Locales Municipales. Entre la política y la Administración, Madrid, INAP; Estudios para la reforma de la Administración Pública (2004), Madrid, INAP, pág. 530 y ss.

${ }^{11}$ Esta Ley en la Exposición de Motivos pone de manifiesto la voluntad de que «(...) la actuación corporativa de los miembros de las Corporaciones locales se realice a través de los grupos políticos, con la posibilidad de dotación económica para su funcionamiento siguiendo una regulación similar a la que se contempla en el Reglamento del Congreso de los Diputados para sus grupos políticos.». En la doctrina pueden consultarse, entre otros: GARCÍA DE ENTERRÍA, E. y FERNÁNDEZ-RODRÍGUEZ, T. R. (2011), Curso de Derecho Administrativo, I y II, 15. ${ }^{a}$ edición, civitas; COSCULLUELA MONTANER, L. (2011), Manual de Derecho Administrativo. Parte General, 22. ${ }^{a}$ edición, civitas; MUÑOZ MACHADO, S. (2011), Tratado de Derecho municipal, edición 3. ${ }^{a}$, lustel; COSCULLUELA MONTANER, L.; MEDINA ALCOZ, L.; HERNANDO RYDINGS, M. y CARBONELL PORRAS, E. (dir.) (2012), Crisis económica y reforma del régimen local, Thomson-Reuters, págs. 271-292.

12 La Ley 11/1999 de modificación de la LBRL de 1985, casi catorce años después, asume lo que contemplaba el art. 23 del ROF y formaliza en una norma el funcionamiento de los grupos políticos en las Corporaciones locales.

13 GONZÁLEZ DEL TESO, T. (2005), "Transfuguismo y concejales no adscritos (A propósito de la reforma de la LBRL por la Ley 57/2003), Justicia Administrativa, núm. 27, págs. 52 y 53.
} 
REALA. Nueva Época - N. 9, Abril 2018 - ISSN: 1989-8975 - DOI: 10.24965/reala.v0i9.10511 - [Págs. 110-127]

De nuevo sobre los concejales no adscritos(a propósito de la sentencia del tribunal constitucional 151/2017, de 21 de diciembre)

Lourdes de la Torre Martínez

Este mismo supuesto será de aplicación cuando alguno de los concejales proponentes de la moción haya dejado de pertenecer, por cualquier causa, al grupo político municipal al que se adscribió al inicio de su mandato.»

Resaltamos que la mayoría a la que se refiere el último párrafo del art. 197.1 letra a) es absoluta. La reforma de la LOREG modificó precisamente la moción de censura en el ámbito local con objeto de limitar el transfuguismo político y evitar las situaciones de bloqueo institucional ${ }^{14}$.

La Ley 57/2003, de 16 de diciembre, de Medidas para la Modernización del Gobierno Local (a partir de ahora LMMGL de 2003) ${ }^{15}$ incluye, por vez primera, en una norma jurídica al concejal no adscrito e incorpora a nuestro ordenamiento jurídico esta figura ${ }^{16}$. Con relación al reconocimiento de los derechos que se reconocen a favor de los concejales no adscritos ${ }^{17}$ se puede afirmar que la LMMGL de 2003 marca un antes y un después ${ }^{18}$. Aunque la regulación vigente de los concejales no adscritos pretende erradicar el transfuguismo

14 RODRÍGUEZ-ARANA, J. (dir.) y CALVO CHARRO, M. (coord.) (2002), La Administración Pública española, INAP, pág. 402.

15 Sobre la Ley 57/2003 de Medidas para la Modernización del Gobierno Local se ha escrito bastante como demuestran, entre otras muchas, las siguientes citas: PAREJO ALFONSO, L. (2004), "Una visión sobre el gobierno local", Anuario del Gobierno Local 2004, El Gobierno local en la reforma del Estado de las autonomías, Fundación Democracia y Gobierno Local, pág. 67; SÁNCHEZ MORÓN, M. (2004), "Balance de la reforma legal sobre el régimen de los «municipios de gran población»", Anuario del Gobierno Local 2004, El Gobierno local en la reforma del Estado de las autonomías, Fundación Democracia y Gobierno Local, pág. 48; COBO OLVERA, T. (dir.), (2004), Ley de Bases del régimen local. Comentarios, concordancias y jurisprudencia. Adaptada a la Ley de Medidas para la Modernización del Gobierno Local, Barcelona, Bosch; ZAFRA VícTOR, M. (2004), "Reflexiones sobre el gobierno local", Anuario del Gobierno Local 2004, El Gobierno local en la reforma del Estado de las autonomías, Fundación Democracia y Gobierno Local, págs. 106-113; RODRÍGUEZ ÁLVAREZ, J. M. (2004), "Génesis y directrices de la Ley 57/2003, de 16 de diciembre, de Medidas para la Modernización del Gobierno Local", La Ley de Modernización del Gobierno Local, Estudis 17, Fundacó Carles Pi i Sunyer d'estudis autonomics i locals, pág. 32; JIMÉNEZ ASENSIO, R. (2004), "Ley de Modernización y Régimen Local: una perspectiva constitucional”, La Ley de Modernización del Gobierno Local, Estudis 17, Fundacó Carles Pi i Sunyer d'estudis autonomics i locals, pág. 282 y ss.; CASTILLO BLANCO, F. A. (2004), "Órganos superiores y directivos en la Ley de Modernización del Gobierno Local", La Ley de Modernización del Gobierno Local, Estudis 17, Fundacó Carles Pi i Sunyer d'estudis autonomics i locals, págs. 240 y 241; DOMINGO ZEBALLOS, M. J. (coord.) (2005), Comentarios a la Ley Básica de Régimen Local, Ley 7/1985, de 2 de abril, Reguladora de las Bases del Régimen Local, segunda edición, Thomson-civitas; REBOLLO PUIG, M.; IZQUIERDO CARRASCO, M. (2006), Comentarios a la Ley Reguladora de las Bases del Régimen local, Tirant lo Blanch.

${ }_{16}$ Es decir, cinco años después de que nazca el concepto de concejal no adscrito en el ámbito político del primer Acuerdo Antitránsfuga de 1998, como ya sabemos, se incorpora a una norma: LMMGL de 2003. La doctrina sobre concejales no adscritos posterior a la LMMGL de 2003 es significativa. Entre otros: REINOSO CARREIRO, A. (2007), "La moción de censura y la realidad del transfuguismo. Los miembros de las Corporaciones Locales «no adscritos»", Consultor de los ayuntamientos y de los juzgados, núm. 2, pág. 231; FERNÁNDEZ-CORREDOR SÁNCHEZ-DIEZMA, J. (2008), "Administración local. Concejales no adscritos", CEFLegal: revista práctica de derecho. Comentarios y casos prácticos, núm. 87, págs. 125-133; NOGUEIRA MARTíNEZ, D. (2011), "El ámbito de aplicación del estatuto legal de los representantes locales no adscritos", Anuario de Derecho Municipal, núm. 5, págs. 63-96; GARCíA GARCÍA, E. (2011), "Grupos políticos municipales: constitución y modificaciones. Concejales no adscritos", Consultor de los ayuntamientos y de los juzgados, núm. 10, págs. 1.265-1.281; CABEZUELO VALENCIA, D. (2012), "Concejales no adscritos. Participación en comisiones informativas", La administración práctica: enciclopedia de administración municipal, núm. 10, págs. 928-932; BALLINA DÍAZ, D. (2012), "Los miembros no adscritos de las corporaciones locales. Novedades jurisprudenciales y legislativas", Consultor de los ayuntamientos y de los juzgados, núm. 5, págs. 577-584; DE LA TORRE MARTíNEZ, L. (2012), "El derecho de los concejales no adscritos a participar en las comisiones informativas con voz y con voto (a propósito de la Sentencia del TC 20/2011, de 14 de marzo)", en libro colectivo dirigido por GARCÍA DE ENTERRÍA, E. y ALONSO GARCÍA, R., Administración y Justicia. Un análisis jurisprudencial. Liber amicorum al Prof. Tomás Ramón Fernández, tomo I, Thomson-Civitas, págs. 345-371; ARRUEGO RODRÍGUEZ, G. (2013), "Sobre la constitucionalidad del «diputado no adscrito»", Revista Española de Derecho Constitucional, año 33, núm. 99, págs. 99-124; FERNÁNDEZ HERNÁNDEZ, O. M. (2013), "El concejal no adscrito. Evolución normativa y jurisprudencial", Consultor de los ayuntamientos y de los juzgados, núm. 4, págs. 370-379; BALLINA DÍAZ, D. (2013), “¿Pueden los concejales no adscritos ejercer competencias delegadas en régimen de dedicación parcial o exclusiva”, Cuadernos de derecho local, núm. 32, págs. 145-150; DÍEZ QUESADA, A. (2013), "La participación de los miembros de las corporaciones locales no adscritos en las comisiones informativas: Comentarios a la luz de la sentencia del Tribunal Constitucional 246/2012, de 20 de diciembre”, Consultor de los ayuntamientos y de los juzgados, núm. 24, págs. 2.381-2.391; DE LA TORRE MARTíNEZ, L. (2014), "La lucha por la equiparación de los derechos en los miembros de las corporaciones locales: ¿del premio al castigo?", Revista Española de Derecho Administrativo, núm. 63, págs. 353-386; DE LA TORRE MARTÍNEZ, L. (2014), El estatuto jurídico de los concejales no adscritos, Fundación democracia y gobierno local, serie: debates locales 4; De la TORRE MARTÍNEZ, L. (2015), "El régimen estatutario de los electos locales: ¿es norma básica estatal en sentido material y formal?", en REBOLLO PUIG, M.; CARBONELL PORRAS, E.; LÓPEZ BENÍTEZ, M., Régimen Jurídico Básico de las Administraciones Públicas. Libro Homenaje al Profesor Luis Cosculluela, lustel, págs. 330-347.

17 ARRÓNIZ MORERA DE LA VALL, M. A. (2009), "El estatuto del concejal no adscrito y el derecho fundamental del artículo 23.2 CE", Revista Española de la Función Consultiva, núm. 12, págs. 165 a 167; CUERDA MÁs, J. (2010), "Régimen jurídico de los concejales son adscritos", Revista CEMCI, núm. 9, págs. 17 a 19; LÓPEZ FERNÁNDEZ, F. J. (2011), "Los grupos políticos y las comisiones informativas de las Entidades locales: tratamiento práctico y jurisprudencial", Jornada sobre Constitución de nuevas Corporaciones Locales, Cádiz, Cosital.

18 El art. 73.3 LBRL ha generado muchas críticas doctrinales. GALÁN GALÁN, A. (2004), El reglamento orgánico local, Madrid, MAP, pág. 59 y ss; BALLESTEROS FERNÁNDEZ, A. (2006), Manual de Administración Local, 5. ${ }^{a}$ edición, Madrid, La Ley El Consul- 
REALA. Nueva Época - N. 9, Abril 2018 - ISSN: 1989-8975 - DOI: 10.24965/reala.v0i9.10511 - [Págs. 110-127]

De nuevo sobre los concejales no adscritos(a propósito de la sentencia del tribunal constitucional 151/2017, de 21 de diciembre)

Lourdes de la Torre Martínez

en el ámbito local, la normativa de 2003 es aplicable no sólo a los supuestos de transfuguismo, sino también a los de los concejales no adscritos no tránsfugas. De hecho, el legislador estatal, aun teniendo la posibilidad posteriormente, no ha querido hacerlo de otra forma con la aprobación de la Ley 27/2013, de 27 de diciembre, de racionalización y sostenibilidad de la Administración Local ${ }^{19}$.

Para completar este estudio, no podemos olvidar que el art. 73 de la LBRL remite a las Comunidades Autónomas la posibilidad de desarrollar los derechos que les corresponden a estos concejales y también al Reglamento orgánico de cada Corporación local ${ }^{20}$. Por tanto, es necesario analizar en conjunto la legislación básica estatal, la legislación autonómica de desarrollo y el Reglamento orgánico municipal de cada Corporación local. Recordemos que el art. 73.3 LBRL es una materia básica regulada por el legislador estatal con base al título competencial del art. 149.1.18 CE («bases del régimen jurídico de las Administraciones Públicas»), pero que puede ser desarrollada por las Comunidades Autónomas ${ }^{21}$.

La competencia normativa de las Comunidades Autónomas para desarrollar los aspectos no básicos del régimen estatutario de los miembros electos locales fue confirmada por la Sentencia del TC 103/2013, de 25 de abril ${ }^{22}$. El TC, tras delimitar los títulos competenciales aquí aplicables, entra a co-

tor, pág. 136 y ss.; NAVARRO MÉNDEZ, J. I. (2000), "Patología del transfuguismo político. Grandes males, pero ¿buenos remedios?", RCG, núm. 49, págs. 41 a 45; ALONSO MÁS, M. J. (2005), "El discutible régimen jurídico de los concejales no adscritos", Revista de Administración Pública, núm. 168, págs. 104 y 105; VILLALBA PÉREZ, F. (2006), "El estatuto de los cargos representativos locales en las reformas del Régimen local", Revista de Estudios Locales, número extraordinario, pág. 59 y ss.

19 Existen numerosos trabajos doctrinales sobre la Ley 27/2013. EI VIII Congreso de la Asociación Española de Profesores de Derecho Administrativo, celebrado en Alicante, los días 8 y 9 de febrero de 2013, ya ponía en tela de juicio algunas de las modificaciones que se pretendía introducir y así se recoge en las actas publicadas en DÍEZ SÁNCHEZ, J. J. (coord.) (2013), La planta del Gobierno Local, Barcelona, Fundación Democracia y Gobierno Local. También pueden verse las obras colectivas: DOMINGO ZEBALLOS, M. J. (coord.) (2014), Reforma del Régimen Local. La Ley de Racionalización y Sostenibilidad de la Administración Local: veintitrés estudios, Cizur Menor (Navarra), Thomson Reuters Aranzadi; SANTAMARÍA PASTOR, J. A. (coord.) (2014), La reforma de 2013 del régimen local español, Fundación Democracia y Gobierno Local; QUINTANA LÓPEZ, T. (dir.), y CASARES MARCOS, A. B. (coord.) (2014), La reforma del régimen local, Valencia, Tirant lo Blanch; Díaz Lema (coord.), (2014), Sostenibilidad financiera y Administración local. Un estudio comparado, Valencia, Tirant lo Blanch, Valencia; CARRILLO DONAIRE, J. A. (coord.), y NAVARRO RODRÍGUEZ, P. (2014), La reforma del Régimen Jurídico de la Administración Local. El nuevo marco regulatorio de la Ley de racionalización y sostenibilidad de la Administración Local, Madrid, La Ley-El Consultor de los Ayuntamientos; MEDINA GUERRERO, M. (2014), La reforma del régimen local, Valencia, Tirant lo Blanch; ALMEIDA CERREDA, M. (dir.) y SANTIAGO IGLESIAS, D. (coord.) (2015), La racionalización de la organización administrativa local: las experiencias española, italiana y portuguesa, Cizur Menor (Navarra), Civitas Thomson Reuters; RODRíGUEZ ARANA, J. y SARMIENTO ACOSTA, M. J. (2014), Comentarios a la Ley 27/2013, de 27 de diciembre, de Racionalización y Sostenibilidad de la Administración local, Granada, Comares. Otros trabajos sobre diversas cuestiones suscitadas por la LRSAL: CARBONELL PORRAS, E. (2014), "Sobre la reforma local y las competencias municipales propias", en Revista Vasca de Administración Pública núms. 99/100, número especial en recuerdo y homenaje al Profesor Demetrio Loperena, págs. 765-766; BEGINES PAREDES, J. M. (2015), "El conflicto competencial en aplicación de la LARSAL en los entes locales. La evolución de un año para no olvidar", Revista de Estudios Locales núm. 178; MERINO ESTRADA, V. (2016), “¿Qué fue de la reforma local?”, Revista de Estudios Locales, núm. 190, págs. 18-10; BARRERO RODRÍGUEZ, C. (2017), "La Ley de reforma del régimen local de 2013: ¿ha modificado realmente las competencias de los municipios?", REDA, núm. 184; MARTíN REBOLLO, L. y ALEGRE ÁVILA, J. M. (2017), "Las competencias locales en la STC 41/2016, de 3 de marzo", PAREJO ALFONSO, L. y VIDA FERNÁNDEZ, J. (coord.) (2017), Los retos del Estado y la Administración en el siglo XXI. Libro homenaje al profesor Tomás de la Quadra-Salcedo Fernández del Castillo, Valencia, Tirant lo Blanch, II, 2017, pág. 2.015 y ss.; PIZARRO NEVADO, R. (2016), "Disposiciones generales, principios de actuación y funcionamiento del sector público", en GOSÁLBEZ PEQUEÑO, H. (dir.) (2016), El nuevo régimen jurídico del sector público, Madrid, Wolters Kluwer, págs. 137 y ss. y PIZARRO NEVADO, R. (2017), "Significación y claves de la Ley de Régimen Jurídico del Sector Público", en Revista Gallega de Administración Pública, núm. 53, pág. 327 y ss.

${ }_{20}$ Recordemos el contenido de la Sentencia temprana del TC 214/1989, de 21 de diciembre. El TC afirma que existe una relación de subordinación del Reglamento orgánico local a la legislación autonómica, de tal modo que si la regulación autonómica regulara los derechos de los concejales no adscritos de forma restrictiva, el Reglamento orgánico municipal no podría mejorar la situación jurídica relativa a estos concejales. EI TC trata de preservar un espacio normativo para la legislación autonómica de desarrollo en materia de organización.

${ }^{21}$ Esta afirmación se proclama por el TC de forma temprana en la Sentencia 214/1989, de 21 de diciembre, y de forma más reciente en la STC 103/2013, de 25 de abril. De este modo, la regulación de los grupos políticos, el establecimiento, en su caso, de un número mínimo para los mismos y, en definitiva, el conjunto de derechos de los concejales no adscritos en cada Comunidad Autónoma es diferente. Además debemos tener presente que algunas Comunidades Autónomas regularon esta figura antes de su incorporación en la normativa estatal de 2003, otras con carácter posterior e incluso algunas ni siquiera la han contemplado.

22 Se trata de un recurso de inconstitucionalidad interpuesto por el Parlamento catalán contra varios preceptos de la Ley 7/1985 LBRL en la redacción dada por la LMMGL de 2003, y, en particular, en lo que a nosotros nos interesa, del art. 73.3 en la medida en que lo declara básico. El recurso se ampara en dos parámetros, de un lado, en la garantía constitucional de la autonomía local y, de otro, en los títulos competencias que asisten al Estado y a las Comunidades Autónomas. En esta línea el Parlamento catalán estima que el art. 73.3 LBRL sería inconstitucional, al establecer que los derechos económicos y políticos de los concejales no adscritos se ejercerán en la forma en que se determine en el reglamento orgánico de cada corporación. Esta tacha de inconstitucionalidad del precepto, a juicio del Parlamento catalán, se debe a que con el mismo se está desconociendo la capacidad normativa de la Co- 
REALA. Nueva Época - N. 9, Abril 2018 - ISSN: 1989-8975 - DOI: 10.24965/reala.v0i9.10511 - [Págs. 110-127]

De nuevo sobre los concejales no adscritos(a propósito de la sentencia del tribunal constitucional 151/2017, de 21 de diciembre)

Lourdes de la Torre Martínez

nocer la constitucionalidad de cada uno de los preceptos impugnados, en particular de la Disposición Adicional primera de la LMMGL por declarar básico el art. 73.3 LBRL, por conexión con los arts. 20.1 c) y 122.3 de la misma norma ${ }^{23}$.

Por tanto, a la luz de las diferentes opciones tomadas en cada Comunidad Autónoma ${ }^{24}$ en relación a la regulación de los grupos políticos, del grupo mixto en su caso, y de la figura de los concejales no adscritos $^{25}$, podemos afirmar que la legislación estatal básica -la LBRL- podía haber fijado de antemano un conjunto de derechos mínimos aplicables a los concejales no adscritos, ya que muchos otros derechos de participación corresponden a los concejales por el simple hecho de integrarse en grupos municipales.

Lo cierto es que ni la legislación vigente aplicable ni la jurisprudencia recaída han podido dar respuesta a la amplia y variada problemática que se genera en torno a la controvertida figura de los concejales no adscritos. Buena muestra de ello es la reciente Sentencia del TC 151/2017, de 21 de diciembre, por la que se resuelve una cuestión de inconstitucionalidad (recurso núm. 5210-2014), planteada por el Tribunal Superior de Justicia de Canarias (en adelante TSJ), con sede en Santa Cruz de Tenerife, respecto del art. $197.1 \mathrm{a}$ ), párrafo tercero, en relación con el párrafo segundo de la LOREG, por posible vulneración del art. $23.2 \mathrm{CE}$. Como veremos en los apartados siguientes, en esta Sentencia el TC declara la inconstitucionalidad y nulidad del párrafo tercero del apartado 1.a) de la LOREG.

munidad Autónoma, es decir de la Generalidad, para regular los aspectos no básicos del régimen estatutario de los electos locales, debiéndose extender además la inconstitucionalidad a todo el precepto por conexión con los arts. $20.1 \mathrm{c}$ ) y 122.3. Antes de entrar de lleno en el fondo de la cuestión planteada el TC trata de delimitar los títulos competencias de aplicación (FJ 4) y recuerda su doctrina temprana al respecto (FJ 5). En tal supuesto, el TC incluso tuvo en cuenta que el Estatuto de Autonomía de Cataluña ha sido modificado con posterioridad a la interposición de este recurso de inconstitucionalidad por la Ley Orgánica 6/2006, siendo ahora el art. 160 el que atribuye a la Generalidad competencias exclusivas y compartidas en materia de régimen loca. Véase la Sentencia del TC 103/2013, de 25 de abril (FJ 5).

${ }^{23}$ El alto intérprete de la Constitución aclara que los reproches de los recurrentes en este precepto no se dirigen a toda la regulación contenida en el art. 73.3 LBRL, sino únicamente en lo relativo a la figura de los concejales no adscritos. En realidad, el Tribunal considera que el artículo impugnado lo único que hace es atribuir al Reglamento orgánico de cada Corporación «la regulación del ejercicio de los derechos económicos y políticos de los concejales no adscritos, como manifestación de la potestad normativa inherente a la autonomía municipal. Ello sin perjuicio de que, en el ejercicio de su competencia normativa, el Pleno deba necesariamente respetar lo establecido en la legislación estatal, a la que tampoco este apartado se refiere, como en la legislación autonómica de desarrollo, razón por la cual debe descartarse la inconstitucionalidad del art. 73.3 LBRL y, por conexión, los arts. 20.1 c) y 122.3 y de la disposición final primera en lo que a estos se refiere» (FJ 5 letra f). Cuestión distinta al objeto de nuestro estudio es la declaración por el TC de inconstitucionalidad en esta Sentencia del art. 126.2 LBRL, en la redacción dada por la LMMGL, que se limita a la facultad que se reconoce al Alcalde para nombrar como miembros de la Junta de Gobierno a personas que no ostenten la condición de concejales, pues es contrario al principio democrático que se plasma de forma expresa en los arts. 140 y 141.2 CE, con la elección de concejales y alcaldes y que encomienda el gobierno y la administración de las provincias a Diputaciones u otras corporaciones de carácter representativo. STC 103/2013, de 25 de abril (FJ 6).

24 Puede consultarse en la doctrina: CARBONELL PORRAS, E. (2011), "La Administración local en el estatuto de autonomía de 2007 y en la reciente legislación andaluza", en MUÑOZ MACHADO, S. (2011), Tratado de Derecho Municipal, capítulo IXXI, lustel, págs. 4.521 a 4.562.

25 Por ejemplo podemos observar la regulación de distintas Comunidades Autónomas con el fin de analizar el tratamiento que otorgan a los concejales no adscritos. La Ley 5/1997, de 22 de julio, de Administración local de Galicia no contempla ninguna norma específica sobre los concejales no adscritos. En relación a los derechos que las normas autonómicas reconocen a los concejales no adscritos resaltamos que el Decreto Legislativo 2/2003, de 28 de abril, por el que se aprueba el Texto Refundido de la Ley municipal y de régimen local de Cataluña y la Ley 1/2003, de 3 de marzo, de la Administración Local de la Rioja disponen que los concejales no adscritos «tienen los deberes y los derechos individuales, incluidos los de carácter material o económico que según las leyes forman parte del estatuto de los miembros de las Corporaciones Locales y participan en las actividades propias del Ayuntamiento de manera análoga a la del resto de concejales» (art. 50.6 del Texto Refundido de la Ley Municipal y de Régimen Local de Cataluña y art. 112.1 de la Ley de Administración Local de La Rioja). Por su parte, la Ley de La Rioja y la Ley 7/1999, de 9 de abril, de Administración local de Aragón contemplan que «los concejales no adscritos, al no pertenecer a ningún grupo político municipal, no tendrán portavoz» (art. 123.1 de la Ley de La Rioja y art. 112.1 de la Ley aragonesa) y, además, que el «miembro de la Corporación que deje de pertenecer a su grupo de origen perderá el puesto que ocupare en las comisiones para las que hubiese sido designado por dicho grupo, así como la posibilidad de tener reconocida dedicación exclusiva» (art. 122.6 de la Ley de La Rioja y art. 111.6 de la Ley aragonesa). La Ley 2/2003, de 11 de marzo, de Administración local de la Comunidad de Madrid, señala que el concejal no adscrito «tendrá los derechos que individualmente correspondan como miembro de la Corporación, pero no los derivados con carácter exclusivo de su pertenencia a un grupo político» (art. 32.4 párrafo 2). La Sentencia 246/2012, de 20 de diciembre, del Pleno del Tribunal Constitucional, recaída en las cuestiones de inconstitucionalidad acumuladas núms. 1992/2010 y 7128/2010, declara que el segundo párrafo del art. 32.4 de la Ley 2/2003, de 11 de marzo, de Administración Local de la Comunidad de Madrid no es inconstitucional, interpretado en los términos establecidos en el FJ 7 de dicha Sentencia. La ley 5/2010, de 11 de junio, de Autonomía Local de Andalucía no contempla nada en relación a los concejales no adscritos. 


\section{LA SENTENCIA DEL TRIBUNAL CONSTITUCIONAL 151/2017, DE 21 DE DICIEMBRE}

La doctrina que ha instaurado el TC con la STC 151/2017 en esta materia es novedosa, pues viene a cerrar el debate en diversas cuestiones suscitadas en torno a los concejales no adscritos y resaltamos su importancia al ser la primera en la que el alto Tribunal de forma explícita entiende que la ruptura de un concejal con su partido político no siempre tiene naturaleza fraudulenta.

En este supuesto, el TC trata de dilucidar si el artículo 197.1 a) LOREG, acerca del cual presentó una cuestión de constitucionalidad el TSJ de Canarias, es conforme a la Constitución y si vulnera el derecho a la participación política del artículo $23.2 \mathrm{CE}$, en la medida en que el precepto de la LOREG exige un quórum reforzado cuando entre los firmantes de la propuesta de moción de censura haya concejales no adscritos por cualquier causa. Recordemos que la exigencia de ese quorum reforzado es el resultado de aplicar las medidas contra el transfuguismo sin distinguir las circunstancias de cada caso y como requisito para tramitar en el pleno de un ayuntamiento las propuestas de moción de censura.

EI TC, en este asunto, ha entendido que esta postura no es legítima, porque el cese de la relación de un concejal con su partido no necesariamente responde a una defraudación de la voluntad popular ni a la búsqueda de la desestabilización de la dinámica municipal. Así, el alto Tribunal considera que el precepto cuestionado de la LOREG vulnera el derecho fundamental a la participación política ${ }^{26}$ contemplado en el artículo $23 \mathrm{CE}$, al exigir un quórum reforzado cuando entre los firmantes de la propuesta de moción haya concejales que, por cualquier causa, hayan dejado de pertenecer al grupo político del Alcalde y no estén adscritos a ningún partido.

\section{Antecedentes de hecho}

Una vez celebradas las elecciones locales, el 22 de mayo de 2011, y la sesión pública de constitución del Ayuntamiento de Tacoronte (Tenerife), el 11 de junio de 2011, resultó proclamado el Alcalde-Presidente de la Corporación local del Grupo de Coalición Canaria con trece votos favorables del total de los veintiún miembros electos. Casi dos años después, el día 9 de octubre de 2013, once concejales del Ayuntamiento (todos los del Grupo Popular y cinco de los seis pertenecientes al Grupo Socialista), de los veintiún miembros de la Corporación, presentaron una moción de censura contra el Alcalde apoyando otra candidatura (encabezada por uno de los concejales socialistas). A continuación, se comunicó a la Secretaría General de la Corporación la expulsión definitiva del partido político de los cinco concejales del Grupo Municipal Socialista firmantes de la moción, señalándose la nueva composición del Grupo Municipal (integrado por el concejal restante $)^{27}$. La sesión en la que se aprobó la moción de censura se celebró el día 22 de octubre de 2013, con once votos a favor, ocho en contra y dos abstenciones, proclamándose Alcalde al nuevo candidato propuesto.

Seguidamente, el Alcalde objeto de la moción, invocando la vulneración del art. 23.2 CE, interpuso recurso contencioso-administrativo por el procedimiento especial de protección de derechos fundamentales contra los Acuerdos adoptados el día 22 de octubre de 2013 por la Mesa de edad y el Pleno del Ayuntamiento de Tacoronte, por los cuales se acordó la tramitación de la moción de censura, su destitución y designación de un nuevo Alcalde ${ }^{28}$.

${ }^{26}$ Los estudios sobre los derechos fundamentales son abundantes, destacamos: Jiménez-Blanco Carrillo de ALBORNOZ, A. (1991), "Garantías institucionales y derechos fundamentales en la Constitución", en MARTíN RETORTILLO BAQUER, S. (coord.), Estudios sobre la Constitución española: Homenaje al Profesor Eduardo García de Enterría, vol. 2 (Derechos y deberes fundamentales), págs. 635-650; ALARCÓN SOTOMAYOR, L. (2009), "Derechos Fundamentales", RGDA, núm. 20, lustel; DE ASIS ROIG, R. (2000), Las paradojas de los derechos fundamentales como límites al poder, Instituto de Derechos Humanos Bartolomé de las Casas, Universidad Carlos III, Dykinson; ARZOZ SANTISTEBAN, X. (2015), La tutela de los derechos fundamentales de la Unión Europea por el Tribunal Constitucional, INAP.

${ }^{27}$ El 11 de octubre de 2013, el Secretario de Organización comunicó a la Secretaría General del Ayuntamiento la expulsión provisional del partido de los concejales socialistas firmantes de la moción, señalando que el Grupo Municipal Socialista quedaría compuesto exclusivamente por un concejal. El día 18 de octubre de 2013 se comunicó a la Secretaría General de la Corporación la expulsión definitiva del partido político de los cinco concejales del Grupo Municipal Socialista firmantes de la moción, acordada por resoluciones de esa misma fecha de la Comisión Ejecutiva Federal del PSOE, reiterándose la nueva composición del Grupo Municipal (integrado por el concejal restante).

${ }^{28}$ La demanda se fundamenta en el incumplimiento de la mayoría reforzada exigida por el art. 197.1 a), párrafo tercero, LOREG, y en la no verificación de dicha mayoría por la Mesa de edad, según dispone el apartado e) del citado precepto, en la redacción dada por la Ley Orgánica 2/2011, de 28 de enero. 


\subsection{La Sentencia del Juzgado de lo Contencioso-Administrativo de Santa Cruz de Tenerife}

El Juzgado de lo Contencioso-Administrativo núm. 4 de Santa Cruz de Tenerife, mediante Sentencia de 5 de febrero de 2014, considera que estamos en presencia de una causa de transfuguismo, recogida en el párrafo tercero del art. 197.1 a) LOREG, y a la que resulta de aplicación también el art. 73.3 LBRL, con la pérdida de adscripción de los concejales expulsados del Grupo Municipal Socialista tras enjuiciar el procedimiento disciplinario seguido internamente en dicho Grupo. A su juicio, la propuesta de moción de censura debía ser apoyada por la mayoría absoluta del número legal de miembros de la Corporación, incrementada en el mismo número de concejales que los que dejaron de pertenecer al Grupo Municipal Socialista.

Finalmente, el Juzgado de la Contencioso-Administrativo acogió la pretensión de la parte actora, declaró vulnerado el art. 23.2 CE y anuló los Acuerdos de 22 de octubre de 2013, con reconocimiento del derecho del recurrente a ser restablecido en el cargo de Alcalde-Presidente del Ayuntamiento de Tacoronte.

\subsection{El recurso de apelación ante el TSJ de Canarias y planteamiento de la cuestión de inconstitucionalidad con relación al artículo 197.1 a) LOREG, párrafo tercero, por vulneración del artículo 23.2 CE}

Por su parte, los cinco concejales expulsados del PSOE interpusieron recurso de apelación contra la Sentencia de 5 de febrero de 2014 citada, alegando varios motivos, entre los que se encontraba el de interpretación errónea, en la Sentencia de instancia, sobre el párrafo tercero del art. 197.1 a) LOREG, que regiría únicamente supuestos de abandono voluntario del grupo político, no así casos de expulsión, menos aun cuando es la mayoría del grupo la que sostiene la moción de censura, como ocurría en esta ocasión. Los concejales del PP firmantes de la moción de censura recurrieron igualmente la citada sentencia, coincidiendo en las alegaciones a las ya expuestas.

Conclusa la tramitación del recurso de apelación, y dentro del plazo señalado para dictar sentencia, el TSJ de Canarias, (de acuerdo con el art. 35.2 LOTC) solicitó a las partes y al Ministerio Fiscal que formularan alegaciones sobre la pertinencia de plantear cuestión de inconstitucionalidad en relación al artículo 197.1 a) LOREG por infringir el artículo 23.2 CE al privar del derecho al ejercicio del cargo público a los concejales disidentes con las instrucciones de los órganos directivos de sus partidos con ocasión de la votación de las mociones de censura, porque establece medidas equivalentes a la privación del derecho a voto en los plenos donde se decide la moción de censura.

Mediante Auto de 31 de julio de 2014, el TSJ de Canarias fundamenta la cuestión de inconstitucionalidad en tres motivos: 1) el precepto cuestionado opera para los supuestos de baja voluntaria en la formación política y también para casos de salida forzosa, como sucede en el caso de la expulsión por sanción disciplinaria ${ }^{29} ; 2$ ) el precepto cuestionado se aplica a los concejales que dejan el grupo, con independencia de que sean mayoría o minoría de sus integrantes ${ }^{30} ;$ y 3 ) considera que se dan los presupuestos de hecho para exigir la mayoría reforzada en la propuesta de moción de censura ${ }^{31}$.

En cuanto a los motivos de fondo de la cuestión de inconstitucionalidad, el TSJ alega que la medida cuestionada y establecida para combatir el transfuguismo supone limitaciones al ejercicio del cargo público de los concejales no adscritos. Estas limitaciones afectan de forma directa al núcleo esencial de la función representativa que tienen atribuida en el art. 23.2 $\mathrm{CE}^{32}$. En particular, se refiere a la facultad de control de la acción de gobierno a través del apoyo en mociones de censura. En este contexto, el TSJ resalta que el incremento de la mayoría absoluta requerida con carácter general convierte la posibilidad de que dichos concejales promuevan una moción de censura en meramente nominal, privando a sus apoyos de efecto alguno.

29 La LOREG indica de forma expresa que será «por cualquier causa», mientras que el art. 73.3 LBRL dispone que los concejales expulsados de la formación política con la que concurrieron a las elecciones dejarán de pertenecer al grupo político y serán considerados no adscritos.

30 Según el TSJ así lo acredita el art. 73.3 LBRL y del citado precepto se desprende que cuando la mayoría del grupo político municipal deja de pertenecer a la formación política permanece en el grupo político la minoría, siendo la mayoría saliente la afectada por las normas contra el transfuguismo.

31 EI TSJ rechaza en ese punto la alegada falta de efectos de la expulsión en el momento de celebrarse la sesión plenaria por cualquiera de las siguientes causas: por no haberse seguido un procedimiento contradictorio para imponer la sanción, por haberse dictado la resolución sancionadora por órgano incompetente, por no haber sido notificada ésta a los interesados o, finalmente, por no ser ejecutiva en tanto estuviera pendiente de resolución el recurso interno previsto estatutariamente (art. 66.2 del Reglamento de afiliados y afiliadas del PSOE).

32 MARTÍN NÚÑ̃Z, E. (1996), El régimen constitucional del cargo público representativo, Barcelona, CEDECS, págs. 68 y 69. 
Además, a juicio del TSJ, esas restricciones, aunque se hayan aprobado para luchar contra el transfuguismo, al incidir en el núcleo esencial de la función representativa (art. 23.2 CE), no pueden venir justificadas ni por la disciplina de partido ni por la relevancia que la Constitución y las leyes electorales confieren a los partidos políticos como canalizadores del pluralismo político ${ }^{33}$.

\subsection{Las alegaciones de las partes}

El Abogado del Estado en representación del Gobierno, el Fiscal General del Estado y el primer Alcalde, siguiendo con el procedimiento legalmente establecido, aportaron sus respectivos escritos de alegaciones, que resumimos por su interés.

El Abogado del Estado formuló escrito de alegaciones solicitando Sentencia desestimatoria, al entender que el juicio ha de hacerse desde la perspectiva del derecho reconocido en el art. 23.2 CE. Con este fin, el Abogado del Estado recuerda que el legislador, mediante el art. 197.1 a) LOREG, concreta su potestad de configuración legal del derecho fundamental conciliando y coordinando normativamente los dos principios que sustentan su reconocimiento constitucional: el principio de soberanía popular y el principio de representatividad democrática, que fundamenta el derecho al ejercicio del cargo electoral. Por tanto, el Abogado del Estado recuerda que el art. 23.2 CE es un derecho de configuración legal y subraya la prevalencia del principio representativo y la necesidad de no defraudar la voluntad popular.

El Fiscal General del Estado interesa la desestimación de la cuestión de inconstitucionalidad y entiende que la restricción impuesta en la LOREG responde a un fin legítimo y no constituye un impedimento artificial, sin que el quórum reforzado que prescribe para la propuesta de una moción de censura anule el ejercicio de la función representativa de los concejales no adscritos.

La representación del primer Alcalde defiende la constitucionalidad de la regulación legal y estima que ninguno de los derechos que integran la función de control político del gobierno local a través de la moción de censura (promoción, proposición como candidato y votación) queda reducido para los concejales no adscritos en el precepto de referencia. Por ello, entiende que el art. 197.1 apartado a) LOREG sobre el quórum inicial para la presentación de la moción de censura no resultaría de aplicación al supuesto de hecho, ya que los cinco concejales del Grupo Socialista pasaron a la condición de no adscritos con posterioridad a la presentación inicial de la moción de censura. En este caso concreto, a su juicio, sería de aplicación el apartado e) art. 197.1 LOREG que regula el quórum de admisión de la moción en un segundo momento, previo a su votación plenaria, lo que no se cumplió en la moción promovida en el Ayuntamiento de Tacoronte.

\section{La fundamentación de la Sentencia}

Esta cuestión de inconstitucionalidad ha sido promovida por la Sala de lo Contencioso-Administrativo del TSJ de Canarias, con sede en Santa Cruz de Tenerife, respecto del art. 197.1 a), párrafo tercero en relación con el segundo, de la LOREG, en la redacción dada por la Ley Orgánica 2/2011, de 28 de enero, ante la posible vulneración del art. 23.2 CE. EI TC ha declarado inconstitucional y nulo el párrafo tercero del art. 197.1 a) de la LOREG al aplicar las medidas previstas para hacer frente al transfuguismo, sin distinguir las circunstancias de cada caso concreto y como requisito para tramitar en el Pleno de un Ayuntamiento las propuestas de moción de censura. Pasamos a analizar la argumentación que emplea el TC para llegar a este fallo.

\subsection{La participación en la actividad de control del gobierno local es una función de todos los concejales y pertenece al núcleo representativo del art. 23.2 CE}

EI TC entiende que párrafo tercero del art. 197.1 a) de la LOREG vulnera el derecho fundamental a la participación política (art. 23.2 CE) ${ }^{34}$, al exigir un quórum reforzado cuando entre los firmantes de la propues-

33 STC 151/2017, de 21 de diciembre, FJ 2.

${ }^{34}$ EI TC trae a colación la doctrina del art. 23.2 CE que consagra la dimensión pasiva del derecho de participación política y reconoce el derecho de los ciudadanos a acceder en condiciones de igualdad a las funciones y cargos públicos con los requisitos que señalen las leyes (FJ 3). El llamado ius in officium -denominación dada por la STC 161/1988, de 20 de septiembre- abraza el derecho a permanecer en el cargo sin perturbaciones ilegítimas. La función del representante como garantía del derecho de participación de los ciudadanos «va unida a la de mandato libre» (STC 10/1983, de 21 febrero, en la cual se señala también que «no es teóricamente 
REALA. Nueva Época - N. 9, Abril 2018 - ISSN: 1989-8975 - DOI: 10.24965/reala.v0i9.10511 - [Págs. 110-127]

De nuevo sobre los concejales no adscritos(a propósito de la sentencia del tribunal constitucional 151/2017, de 21 de diciembre)

ta de moción haya concejales que, por cualquier causa, hayan dejado de pertenecer al grupo político del Alcalde y no estén adscritos a ningún partido, ya que el cese de la relación de un concejal con su partido no responde necesariamente a una defraudación de la voluntad popular.

La Sentencia parte de la delimitación del contenido esencial del derecho fundamental reconocido en el art. 23.2 CE y afirma que el ejercicio de control al gobierno local mediante la promoción de una moción de censura forma parte del núcleo del derecho de participación política ${ }^{35}$. Así pues, la moción de censura a un Alcalde es un medio de control y de exigencia de responsabilidad política por parte del Pleno. Además, a juicio del TC, el incremento del quórum altera el régimen jurídico ordinario de la función representativa de los concejales no adscritos, porque implica que, justo en el momento previo a su votación por el Pleno, el impulso de la moción de censura se apoye en una mayoría absoluta en la que no se tienen en cuenta, como si no formaran parte de la misma, «un número igual al de los concejales no adscritos que la suscriben». El TC considera que la medida de incremento del quórum del art. 197.1 a) de la LOREG es una opción con la que el legislador pretende luchar contra el transfuguismo y, de este modo, asegurar la voluntad popular y la estabilidad municipal, evitando que se modifiquen las mayorías de gobierno.

Llegados a este punto se hace preciso destacar que la limitación impuesta a los concejales no adscritos debe conciliarse también con la libertad de mandato del art. 23.2 CE, que implica que los representantes locales puedan mantenerse en el cargo en caso de expulsión o de abandono de los partidos en cuyas listas fueron elegidos. Por ello, el TC afirma que las funciones esenciales del derecho de participación política se atribuyen a su titular en condiciones de igualdad y no al partido político o grupo en el que se integre. El mandato libre supone «la exclusión de todo sometimiento jurídico del representante, en cuanto tal, a voluntades ajenas» y proscribe "cualquier tipo de sujeción, jurídicamente impuesta, a la confianza de sus electores o de las organizaciones o grupos políticos en que se integre o en cuyas listas hubiera concurrido a las elecciones» ${ }^{36}$.

En consecuencia, según el TC, los miembros de una corporación local, incluidos los concejales no adscritos, cuentan con el derecho y facultad de participar en la actividad de control del gobierno local, encuadrados en el núcleo de su función representativa, recogida en el art. 23.2 CE. Además, la puesta en marcha de un procedimiento extraordinario de elección de nuevo Alcalde y de remoción del anterior, y la facultad de presentar una moción de censura, con los límites y garantías previstos en la legislación ${ }^{37}$ forman parte del núcleo de su función de representación política, siendo su regulación norma de desarrollo directo del art. 23.2 CE.

inimaginable un sistema de democracia mediata o indirecta en la que los representantes estén vinculados al mandato imperativo de los representados» -FJ 3) e incorpora también el derecho a ejercer las facultades de actuación que comporta el desarrollo del cargo. En el FJ 7 se declara que «una vez creados por las normas legales derechos y facultadas (propias del cargo), éstos quedan integrados en el estatus propio de cada cargo con la consecuencia de que podrán sus titulares, al amparo del art. $23.2 \mathrm{CE}$, defender ante los órganos judiciales el ius in officium». En la STC 246/2012, de 20 de diciembre, en su FJ 4, se reitera la doctrina previa en relación al núcleo esencial de la función representativa, y afirma que ésta se corresponde con las funciones que sólo pueden ejercer los titulares del cargo público. EI TC razona que la función representativa se corresponde con las funciones que sólo pueden ejercer los titulares del cargo público «por ser la expresión del carácter representativo de la institución (SSTC 141/2007, FJ 3 y 169/2009, FJ 3, por todas) y de las que no pueden ser privados incluso en el caso de que los titulares del cargo público hayan optado por abandonar el grupo político de procedencia (SSTC 5/1983, FJ 4; 185/1993, FJ 5 y 298/2006, FJ 7, por todas). Por esta razón, entre las funciones que pertenecen al núcleo inherente a la función representativa que constitucionalmente corresponde a los miembros de una corporación local se encuentran, en todo caso, la de participar en la actividad de control del gobierno local, la de participar en las deliberaciones del Pleno de la corporación, la de votar en los asuntos sometidos a votación en este órgano, así como el derecho a obtener la información necesaria para poder ejercer las anteriores (SSTC 169/2009, FJ 3; 20/2011, FJ 4; y 9/2012, FJ 4)». El esquema inacabado en relación al conjunto de derechos que se reconocen a los concejales no adscritos ha tratado de ser completado y delimitado por la jurisprudencia del TC. Se trata de las SSTC 20/2011 de 14 de marzo, 101/2011 de 20 de junio, 102/2011 de 20 de junio, 103/2011 de 20 de junio, $112 / 2011$ de 4 de julio, $113 / 2011$ de 4 de julio, $114 / 2011$ de 4 de julio, 115/2011 de 4 de julio, 116/2011 de 4 de julio, 122/2011 de 12 de julio, $129 / 2011$ de 18 de julio, $130 / 2011$ de 18 de julio, $131 / 2011$ de 18 de julio, 9/2012 de 18 de enero, 14/2012 de 6 de febrero, 30/2012 de 1 de marzo y la Sentencia 103/2013, de 25 de abril. SSTS de 18 de mayo de 2012, de 5 de junio de 2012, de 3 de julio de 2012 y del TC 10/2003, de 28 de enero de 2013. La jurisprudencia citada reitera que el derecho de representación es un derecho individual, no sometido a mandato imperativo de los partidos políticos, que corresponde al concejal y, por ello, el concejal no adscrito conserva intactos sus derechos como tal.

35 A lo anterior se suma que la jurisprudencia constitucional viene fijando que la vulneración de los derechos de los representantes contenidos en el art. 23.2 CE no se verifica con cualquier acto que infrinja el estatus jurídico aplicable, sino que a estos efectos sólo poseen relevancia constitucional los derechos o facultades atribuidos al representante que pertenezcan al núcleo de su función representativa (FJ 3).

36 STC 151/2017, de 21 de diciembre, FJ 3.

37 Con relación a la moción de censura, el TC en el fundamento jurídico 4 de la Sentencia objeto de comentario, recuerda la doctrina constitucional previa. En particular, el TC trae a colación la STC 81/2012, de 18 de abril, FJ 3. De este modo, el TC recuerda de la moción de censura varios aspectos importantes: 1) que se trata de un instrumento clave de las formas de gobierno parlamentario, porque es un mecanismo a través del cual el Legislativo controla la gestión del Ejecutivo y exige responsabilidad política al mismo, configurándose como 


\subsection{Análisis de la constitucionalidad del art. 197.1 a) párrafo tercero LOREG}

Como ya se ha comentado, el art. 197.1 a) párrafo tercero LOREG ofrece una concreción más del marco legal específico del estatus representativo de los concejales no adscritos de los municipios contemplado en el art. 73.3 LBRL. El propósito del art. 197.1 LOREG es que no se modifique la voluntad popular, ni las mayorías de gobierno, ni se cambien los gobiernos municipales, ni se favorezca con ello la regeneración democrática o se vea afectada la estabilidad en la vida municipal.

Por ello, un estudio de la constitucionalidad del art. 197.1 LOREG, a juicio del TC, exige que se tengan en cuenta, al menos, las siguientes consideraciones: 1) El legislador no puede imponer en el derecho de acceso a las funciones y cargos públicos representativos (art. 23.2 CE) restricciones que no tengan un fin legítimo. 2) El art. 23.2 CE determina que su regulación no podrá conllevar restricciones ilegítimas contrarias a la garantía de igualdad. 3) En los cargos que se alcanzan mediante elección popular y tienen naturaleza representativa, los requisitos que señalen las Leyes a que se refiere el art. 23.2 CE sólo serán admisibles cuando sean congruentes con su naturaleza de derecho fundamental ${ }^{38}$.

De ahí la importancia para el alto Tribunal en este contexto del concepto de mandato libre, pues «supone la exclusión de todo sometimiento jurídico del representante a voluntades políticas ajenas y proscribe por ello, en particular, que sobre él se hicieran pesar tanto instrucciones vinculantes en Derecho que pretendieran disciplinar su proceder, como asimismo cualquier tipo de sujeción, jurídicamente impuesta, a la confianza de sus electores (expresada del modo que se pretendiera) o de las organizaciones o grupos políticos en que se integre o en cuyas listas hubiera concurrido a las elecciones. Una sujeción que, de llegar a verificarse, contrariaría adicionalmente sus derechos al mantenimiento en el cargo y a ejercerlo sin constricciones ilegítimas (art. 23.2 CE). Los vínculos y lealtades de orden político de cualesquiera representantes populares son, en definitiva, consustanciales a una democracia representativa en la que los partidos, muy en especial, cumplen los cometidos capitales que enuncia el artículo $6 \mathrm{CE}$, pero es la propia racionalidad de esta forma de gobierno la que impide, precisamente en favor de una representación libre y abierta, que el Ordenamiento haga suyos tales compromisos, prestándoles su sanción y convirtiéndolos, de este modo, en imperativos jurídicos» ${ }^{39}$.

\subsection{Juicio de idoneidad, de necesidad y de proporcionalidad en sentido estricto del artículo art. 197.1 a) párrafo tercero LOREG}

Ahora nos detenemos en el análisis que realiza el alto Tribunal del artículo art. 197.1 a) párrafo tercero LOREG con el fin de desentrañar su constitucionalidad siguiendo tres juicios: el de idoneidad, el de necesidad y el proporcionalidad en sentido estricto. Con este objetivo, el TC trata de valorar si la medida es idónea para alcanzar el fin constitucionalmente legítimo perseguido por ella, previamente enunciado (juicio de idoneidad); si la medida idónea es, además, necesaria, en la medida en que no exista otra medida menos lesiva para la consecución de tal fin con igual eficacia (juicio de necesidad); y, por último, si la medida idónea y menos lesiva resulta ponderada, por derivarse de su aplicación más beneficios o ventajas para el interés general que perjuicios sobre otros bienes o intereses en conflicto (juicio de proporcionalidad en sentido estricto) ${ }^{40}$.

\footnotetext{
un cauce para la manifestación de la extinción de la confianza de las Cámaras en el Ejecutivo; 2) que su virtualidad como mecanismo de control y exigencia de responsabilidad política de los gobernantes por quienes les invistieron de la confianza para serlo ha llevado al legislador a incorporar la moción de censura a otras instituciones que también reúnen las notas de representación democrática y confianza a la hora de elegir al poder ejecutivo, como es el caso de los gobiernos municipales, pese a las indudables diferencias que existen entre el Pleno de un Ayuntamiento o una Asamblea vecinal (en el régimen de concejo abierto) y las Asambleas legislativas y autonómicas; 3 ) que la moción de censura al Alcalde se presenta como un instrumento de naturaleza híbrida, pues es un medio de control y de exigencia de responsabilidad política por parte del Pleno y, por tanto, un mecanismo de relación entre los órganos del gobierno municipal, pero, por otro lado, cuando prospera, implica a su vez una causa de cese del Alcalde inicialmente designado -poniendo fin a la efectividad de la elección inicial-, con la subsiguiente proclamación de uno nuevo; 4) que la moción de censura aparece como una pieza clave de la forma de gobierno local; 5) que la moción de censura local configura el «ius in officium, el estatus representativo de los concejales», ya que, como se atribuye a éstos la iniciativa y, por tanto, la puesta en marcha de un procedimiento extraordinario de elección de nuevo Alcalde y de remoción del anterior, la facultad de presentar una moción de censura con los límites y garantías previstos en la legislación pasa a formar parte del núcleo de su función de representación política, siendo su regulación norma de desarrollo directo del art. 23.2 CE.

${ }^{38}$ EI TC en el FJ 6 de la Sentencia ahora analizada recoge los criterios fijados por la jurisprudencia con este fin.

39 STC 151/2017, de 21 de diciembre, FJ 6.

40 Además, a juicio del TC, «el incremento del quorum de iniciativa tiene como efecto derivado el de dificultar la exigencia de responsabilidad política y remoción del Alcalde por quienes les invistieron de la confianza para serlo, entorpeciéndose de ese modo la verificación de cambios que incidan en la estabilidad en la vida municipal y den lugar a la modificación de gobiernos municipales con
} 
En primer lugar, según el TC, la promoción de la moción de censura en el ámbito local, tal y como aparece definida en el art. 197.1 LOREG, permite la consecución del fin perseguido y se trata de una medida idónea y adecuada para el logro del objetivo que se pretende adopción.

En cuanto al juicio de necesidad, el TC también afirma que la medida legal puede considerarse necesaria, pues el art. 197.1 LOREG sólo establece un reforzamiento del quórum de promoción de la moción de censura sin alterar la dinámica del procedimiento de exigencia de responsabilidad y remoción del Alcalde, «como acredita señaladamente que no se altere el régimen de mayorías de la fase de votación, momento en el que los concejales proponentes que hayan dejado de pertenecer, por cualquier causa, al grupo político municipal al que se adscribieron al inicio de su mandato no ven limitado su derecho, conservando la facultad de participar en la votación como cualquier otro concejal». En consecuencia, según el TC, el precepto cuestionado trata de dificultar la acción de promoción de la moción de censura a los concejales no adscritos, para evitar incidencias en la estabilidad en la vida municipal, sin un escenario de restricción de su derecho en la fase de decisión.

Tras ocuparse de los juicios de idoneidad y de necesidad, el TC se detiene en el en el examen de la proporcionalidad en sentido estricto (FJ7). En primer lugar, a juicio del TC, el art. 197.1 LOREG equipara, en la restricción del derecho, a todos los concejales que hayan dejado de pertenecer al grupo político local al que se adscribieron al inicio de su mandato, sea por la causa que sea, sin hacer distinción en función de las circunstancias que hayan dado lugar al cese de dicha vinculación con el grupo político municipal. Es más, el alto Tribunal considera que cualquier disolución de ese nexo orgánico es contraria en sí misma, considerada a la estabilidad de la vida municipal o del gobierno local, equiparando el respeto de la voluntad popular y del gobierno local a la protección del Alcalde que fue designado, cuando lo cierto es que la representación política, en democracia, es siempre colegiada y el Alcalde, por ello, representa al ayuntamiento, perfilándose las mayorías de acuerdo a los pactos que se establecen. En consecuencia, a juicio del TC, el legislador parte de que «cualquier hipótesis de disolución del vínculo político es merecedora de una intervención que asegure la regeneración democrática, premisa ésta que, ante la descrita falta de determinación normativa que lo fundamente, no puede aceptarse» (FJ 7).

En segundo lugar, según el TC, la restricción opera sobre un criterio estrictamente subjetivo: la desvinculación de los concejales del grupo político local al que se adscribieron al inicio de su mandato. Por ello, el TC entiende que el transfuguismo, como anomalía de nuestro sistema democrático, no puede resolverse por el legislador introduciendo medidas que supongan restricciones al ius in officium e impacten en el ejercicio del cargo público, pues tampoco es cierto que la desvinculación orgánica o política del grupo de origen desestabilice, por defecto o sin excepción, la vida municipal o modifique la voluntad popular. El TC concluye que la norma «sujeta al concejal al grupo político de origen bajo advertencia de restricción de las funciones representativas básicas, sin que ese efecto responda inevitablemente a una defraudación de la voluntad popular o a un hacer que busque la desestabilización de la dinámica municipal, como el Preámbulo de la Ley Orgánica invoca» ${ }^{41}$

Por todo ello, el TC considera que el artículo 23.2 CE resulta violado, porque la legalidad a la que remite es contraria a la Constitución y, en especial, a la naturaleza de la representación política. De ahí que debe declararse inconstitucional (FJ 7).

la participación en el impulso de la moción de censura de concejales que hayan dejado de pertenecer, por cualquier causa, al grupo político municipal al que se adscribieron al inicio de su mandato.». Puede consultarse la STC 89/2017, de 4 de julio, FJ 9.

41 La previsión legal, a juicio del TC, reúne dos elementos necesariamente diferentes en un único parámetro que actualiza la limitación de derechos: $1^{\circ}$ ) La disolución del nexo con el grupo político de origen, factor que solo podría constituir el presupuesto subjetivo de una norma que, a la vista de su concurrencia, procure evitar la repercusión de ciertas prácticas tránsfugas en la estabilidad municipal; $2 .^{\circ}$ ) La razón objetiva que fundamente y desvele su sustento material con relación al legítimo fin de la norma, que el legislador puede atender y regular si lo estima conveniente. Según el TC, el art. 197.1 letra a) LOREG carece por completo de ese fundamento objetivo, entendido como obligado soporte constitucional frente a una medida restrictiva del ius in officium y del mandato libre en el ejercicio del cargo representativo. Finalmente, el TC concluye que la anomalía que ha incidido negativamente en el sistema democrático y representativo y que se ha conocido como transfuguismo no puede intervenirse por el legislador con restricciones al ius in officium que impacten en el ejercicio natural del cargo público al amparo de la libertad de mandato con base en razones asociadas, sin adjetivos, a la vinculación orgánica o política, sin fundamentos añadidos. Sencillamente porque no es cierto que la desvinculación orgánica o política del grupo de origen desestabilice por defecto o sin excepción la vida municipal o modifique la voluntad popular. Así lo demuestran casos como el que está en el origen de este procedimiento constitucional, en el que la razón de la expulsión de los concejales socialistas fue por completo ajena a la vida municipal de Tacoronte, al tener que ver con cuestiones orgánicas y pactos suscritos por su partido político en ámbitos territoriales que lo excedían. El TC concluye que la norma «sujeta al concejal al grupo político de origen bajo advertencia de restricción de las funciones representativas básicas, sin que ese efecto responda inevitablemente a una defraudación de la voluntad popular o a un hacer que busque la desestabilización de la dinámica municipal, como el Preámbulo de la Ley Orgánica invoca» STC 151/2017 (FJ 7). 


\subsection{Alcance $y$ efectos del fallo}

La STC 151/2017 determina el alcance y los efectos de la declaración de nulidad en el fundamento jurídico $8^{42}$. EI TC entiende que la anulación del art. 197.1 letra a) tercer párrafo LOREG podría generar alteraciones en procedimientos de exigencia de responsabilidad política en curso ante la ausencia de un régimen jurídico alternativo y respetuoso con la Constitución, acorde con el principio de igualdad en el ejercicio de las funciones representativas y la prevención de los efectos perversos causados por el transfuguismo en los legítimos fines declarados por la norma.

Por ello, el TC estima que la nulidad derivada de la declaración de inconstitucionalidad tiene que quedar diferida hasta la convocatoria de un nuevo proceso de elecciones locales, según prevé el art. 42.3 LOREG, periodo de tiempo en el que el legislador podrá proceder, en su caso, a sustituir la norma declarada nula a la luz del contenido de la STC 151/2017. Finalmente, esta decisión del Tribunal no ha sido compartida por todos los Magistrados y algunos presentaron voto discrepante.

\section{Los votos particulares}

La sentencia, de la que ha sido ponente el Magistrado Fernando Valdés Dal-Ré, cuenta con dos votos concurrentes de la Magistrada Roca y Ollero y con tres votos discrepantes de los Magistrados Conde-Pumpido, Xiol Ríos y Montoya.

La Magistrada Roca comparte la argumentación y la declaración de inconstitucionalidad, por vulneración del art. 23.2 CE, del párrafo tercero del art. 197.1. a) LOREG, pero no que la sentencia posponga la nulidad del precepto recurrido hasta la celebración de nuevas elecciones locales, según se prevé en el Fundamento Jurídico 8, último párrafo, de la Sentencia. Recordemos al efecto que por nulidad diferida se entiende que la expulsión de la norma, ya declarada inconstitucional, queda aplazada hasta un determinado momento fijado en la Sentencia o hasta la aprobación de una nueva norma que sustituya a la declarada nula a fin de evitar un vacío no conforme con la Constitución.

A juicio de la Magistrada, el TC ha usado tradicionalmente la nulidad diferida de forma prudente y, sin embargo, en este caso se ha prescindido de la citada prudencia y, por ello, considera que su uso ha sido inadecuado. Así pues, la Magistrada considera que esta técnica sirve para preservar determinados valores o bienes a fin de evitarles la afectación que supone la declaración de inconstitucionalidad y nulidad de la norma que les da cobertura. Por eso, la aplicación de la técnica de la nulidad diferida exige determinar con claridad el bien cuya preservación reviste tanta entidad como para romper con la consecuencia lógica de la inconstitucionalidad de una norma, su nulidad y consiguiente expulsión del ordenamiento. En este sentido, la Magistrada estima que en el presente caso no ha quedado acreditado que exista esa incidencia que justifique el mantenimiento de la vigencia de una norma inconstitucional durante casi año y medio, ni tampoco se considera que la pervivencia de la regulación conlleva el sacrificio temporal del derecho fundamental del art. $23.2 \mathrm{CE}$.

En consecuencia, por todo lo anterior, la Magistrada considera que en este supuesto no procedía modular los efectos temporales del fallo, pues no existía razón alguna que justificase tal modulación.

El Magistrado Ollero está de acuerdo con la declaración de inconstitucionalidad del precepto impugnado, pero se opone a que su nulidad se posponga hasta la convocatoria de nuevas elecciones locales, pues ello equivale a establecer que una norma declarada inconstitucional debe seguir en vigor dejando en manos del legislador el momento en que, si lo estima oportuno, deberá sustituirla, considerarla efectivamente nula y, en consecuencia, expulsarla del ordenamiento jurídico.

42 La Sentencia declara la inconstitucionalidad del precepto el tercer párrafo de la letra a) del art. 197.1 LOREG «únicamente en cuanto determina, a raíz de la reiterada remisión de la letra e), que en el momento inmediatamente anterior a la votación de la moción de censura en el plenario debe satisfacerse el quórum del párrafo segundo de la letra a), siempre que alguno de los concejales proponentes de la moción haya dejado de pertenecer, por cualquier causa, al grupo político municipal al que se adscribió al inicio de su mandato y, además, en función de la especialidad del citado párrafo segundo, siempre que no forme o haya formado parte del grupo político municipal al que pertenece el Alcalde cuya censura se propone. No procede, a tenor de lo previsto en el art. 39.1 LOTC, extender esa declaración de inconstitucionalidad por conexión o consecuencia a los restantes supuestos y fases del procedimiento regulados en la letra a) del art. 197.1 LOREG, como tampoco, globalmente, al inciso "constatando para poder seguir con su tramitación que en ese mismo momento se mantienen los requisitos exigidos en los tres párrafos del apartado a)", contenido en la letra e) de ese artículo, al regularse en ellos situaciones adicionales que no han sido objeto de examen en este pronunciamiento y que no concurren en el supuesto de hecho examinado en el proceso del que trae origen la presente cuestión de inconstitucionalidad» (FJ 8). 
REALA. Nueva Época - N. 9, Abril 2018 - ISSN: 1989-8975 - DOI: 10.24965/reala.v0i9.10511 - [Págs. 110-127]

De nuevo sobre los concejales no adscritos(a propósito de la sentencia del tribunal constitucional 151/2017, de 21 de diciembre)

A juicio del Magistrado, se echa en falta una referencia al carácter excesivamente personalizado de la modificación del quórum mayoritario previsto. Al vincularse al número de concejales no adscritos que promovieron la moción de censura, tras haber estado vinculados al grupo municipal del Alcalde, se da paso a una fórmula que se activa intuitu personae, «casi cobrando aires de sanción». Esto la convertiría en una medida no necesaria, en el sentido de que «no exista otra medida menos lesiva para la consecución de tal fin con igual eficacia» (FJ 7). Por ello, el Magistrado no comparte, que la medida propuesta por la norma cuestionada pueda considerarse necesaria.

En suma, se persigue dificultar su acción de promoción de la moción de censura para evitar incidencias en la estabilidad en la vida municipal. De este modo, Ollero estima que, en realidad, el derecho a que se tenga en cuenta el sentido de su voto resulta aniquilado.

Por el contrario, el Magistrado Conde-Pumpido, a cuyo voto particular se adhieren los Magistrados Xiol Ríos y Montoya, considera que la cuestión de inconstitucionalidad debió desestimarse. Estiman que la medida declarada inconstitucional es «equilibrada» y que de su aplicación se derivan «más beneficios o ventajas para el interés general que perjuicios sobre otros bienes o intereses en conflicto, incluido el ius in officium de los concejales». Explican el carácter «legítimo» de la medida, dada la importancia que «para la vida local tiene que se respeten los resultados de los comicios locales»; y resaltan la quiebra que para «la legitimidad del gobierno local y, con ello, del propio sistema democrático» supone el transfuguismo «a los ojos de los ciudadanos».

A juicio del Magistrado Conde-Pumpido, la Exposición de Motivos de la LOREG es muy expresiva de lo que se persigue, pues frente a anteriores elevaciones del quórum, esta última modificación normativa no se limita a elevarlo de forma lineal, sino solo en el concreto número de concejales que hubieran dejado de pertenecer, por cualquier causa, al grupo político municipal al que se adscribieron al inicio de su mandato.

A juicio del Magistrado, en la doctrina constitucional el juicio de proporcionalidad en sentido estricto se identifica como la ponderación de beneficios y perjuicios, no obstante, la Sentencia no realiza ponderación alguna de beneficios y perjuicios para el interés general y para otros bienes o intereses en conflicto, cuando dice que va a ocuparse del juicio de proporcionalidad en sentido estricto. En su lugar aporta diversos argumentos, ninguno de los cuales tiene que ver en realidad con ese juicio. En consecuencia, el parecer del Magistrado disidente es que la medida resulta ponderada, por derivarse de su aplicación más beneficios o ventajas para el interés general que perjuicios sobre otros bienes o intereses en conflicto, incluido el ius in officium de los concejales. En cualquier caso, según el Magistrado, no concurre el «desequilibrio patente y excesivo o irrazonable» entre la medida y la finalidad de la norma al que se refiere nuestra jurisprudencia (STC 55/1996, de 28 de marzo, FJ 9), pues «no cualquier desproporción o falta de equilibrio habrá de ser, desde la perspectiva que nos ocupa, constitucionalmente relevante, sino que sólo lo será aquélla en la que el exceso resulte verdaderamente manifiesto o evidente» (STC 60/2010, de 7 de octubre, FJ 16).

\section{REFLEXIONES FINALES}

La STC 151/2017 supone un beneficio en la configuración de los derechos de los concejales no adscritos derivados del núcleo fundamental y representativo del art. $23.2 \mathrm{CE}$. En particular, nos referimos al reconocimiento a todos los concejales, adscritos y no adscritos, del derecho a la participación en la actividad de control del gobierno local cuando se trata de presentar una moción de censura contra el Alcalde. Este nuevo reconocimiento a favor de los concejales no adscritos se ha logrado con la declaración de nulidad del art. 197.1 letra a párrafo 3 LOREG por el TC, la cual establece un quórum reforzado cuando entre los firmantes de la propuesta de moción haya concejales que, por cualquier causa, hayan dejado de pertenecer al grupo político del Alcalde y no estén adscritos a ningún partido, ya que el cese de la relación de un concejal con su partido no responde necesariamente a una defraudación de la voluntad popular.

Para llegar a la declaración de nulidad del art. 197.1 LOREG, el TC afirma que el ejercicio de control al gobierno local mediante la promoción de una moción de censura forma parte del núcleo del derecho de participación política del art. 23.2 CE. EI TC considera que la medida de incremento del quórum del art. 197.1 a) de la LOREG es una opción con la que el legislador pretende actuar para luchar contra el transfuguismo y, de este modo, asegurar la voluntad popular y la estabilidad municipal, evitando que se modifiquen las mayorías de gobierno. Así pues, el TC con el fin de desentrañar la constitucionalidad del artículo cuestionado procede a realizar tres juicios: el de idoneidad, el de necesidad y el de proporcionalidad en sentido estricto. Una vez que realiza estos juicios, el TC denuncia la falta de proporcionalidad del precepto legal, tras admitir 
REALA. Nueva Época - N. 9, Abril 2018 - ISSN: 1989-8975 - DOI: 10.24965/reala.v0i9.10511 - [Págs. 110-127]

De nuevo sobre los concejales no adscritos(a propósito de la sentencia del tribunal constitucional 151/2017, de 21 de diciembre)

el incremento del quórum como una medida idónea y necesaria para combatir el transfuguismo, en cuanto que equipara en la restricción del derecho a todos los concejales que hayan dejado de pertenecer al grupo político municipal al que se adscribieron al inicio de su mandato, sin diferenciar las circunstancias ni los objetivos, no necesariamente fraudulentos, que pudieron llevar a esa desvinculación. Esta uniformidad implica que cualquier separación del grupo político de origen es contraria en sí misma, considerada a la estabilidad de la vida municipal o del gobierno local. En definitiva, el TC ha entendido que el transfuguismo no puede combatirse por el legislador con restricciones a la promoción de la moción de censura en el sentido que prevé el precepto legal anulado por la Sentencia.

Cuestión diferente a la anterior y discutible -de ahí los votos particulares emitidos por algunos Magistrados-, es que con el fin de preservar el principio de seguridad jurídica, la declaración de inconstitucionalidad del precepto citado no afecta a situaciones jurídicas consolidadas y no será efectiva hasta la próxima convocatoria de elecciones locales, periodo de tiempo en el que el legislador podrá reformar la norma a la luz de la Sentencia aquí analizada.

\section{REFERENCIAS BIBLIOGRÁFICAS}

ABELLÁN, A. M. (1994), "Los representantes y el derecho de participación en el ordenamiento jurídico español", REP, núm. 84, pág. 212 y ss.

ALARCÓN SOTOMAYOR, L. (2009), "Derechos Fundamentales", RGDA, núm. 20, lustel.

ALMEIDA CERREDA, M. (dir.) y SANTIAGO IGLESIAS, D. (coord.) (2015), La racionalización de la organización administrativa local: las experiencias española, italiana y portuguesa, Navarra, Civitas Thomson Reuters, Cizur Menor.

ALONSO MÁS, M. J. (2005), "El discutible régimen jurídico de los concejales no adscritos", Revista de Administración Pública, núm. 168, págs. 98 a 107.

ARRÓNIZ MORERA DE LA VALL, M. A. (2009), "El estatuto del concejal no adscrito y el derecho fundamental del artículo 23.2 CE", Revista Española de la Función Consultiva, núm. 12, págs. 165 a 167.

ARRUEGO RODRÍGUEZ, G. (2013), "Sobre la constitucionalidad del «diputado no adscrito»", Revista Española de Derecho Constitucional, año 33, núm. 99, págs. 99-124.

BALLINA DÍAZ, D. (2012), "Los miembros no adscritos de las corporaciones locales. Novedades jurisprudenciales y legislativas", Consultor de los ayuntamientos y de los juzgados, núm. 5, págs. 577-584.

BALLINA DÍAZ, D. (2013), "¿Pueden los concejales no adscritos ejercer competencias delegadas en régimen de dedicación parcial o exclusiva", Cuadernos de derecho local, núm. 32, págs. 145-150.

BARRERO RODRÍGUEZ, C. (2017), "La Ley de reforma del régimen local de 2013: ¿ha modificado realmente las competencias de los municipios?", REDA, núm. 184.

BEGINES PAREDES, J. M. (2015), "El conflicto competencial en aplicación de la LARSAL en los entes locales. La evolución de un año para no olvidar", Revista de Estudios Locales, núm. 178.

BLANCO VALDÉS, R. L. (1990), Los partidos políticos, Madrid, Tecnos, pág. 55.

BLANCO VALDÉS, R. L. (2003), "Transfuguismo y democracia en la Comunidad de Madrid", Claves de la Razón Práctica, núm. 135, pág. 47.

CABEZUELO VALENCIA, D. (2012), "Concejales no adscritos. Participación en comisiones informativas", La administración práctica: enciclopedia de administración municipal, núm. 10, págs. 928-932.

CAPO GIOL, J. (1999), "El debate sobre el sistema electoral. Imágenes, intereses y propuestas", en Elecciones locales, Madrid, INAP, págs. 143 a 213.

CARBONELL PORRAS, E. (2014), "Sobre la reforma local y las competencias municipales propias", Revista Vasca de Administración Pública, núm. 99/100, número especial en recuerdo y homenaje al profesor Demetrio Loperena, págs. 765-766.

CARRILLO DONAIRE, J. A. (coord.), y NAVARRO RODRÍGUEZ, P., (2014), "La reforma del Régimen Jurídico de la Administración Local. El nuevo marco regulatorio de la Ley de racionalización y sostenibilidad de la Administración Local", Madrid, La Ley-El Consultor de los Ayuntamientos.

CASTILLO BLANCO, F. A. (2004), "Órganos superiores y directivos en la Ley de Modernización del Gobierno Local", en La Ley de Modernización del Gobierno Local, Estudis 17, Fundacó Carles Pi i Sunyer d'estudis autonomics i locals, págs. 240 y 241.

COBO OLVERA, T. (dir.) (2004), Ley de Bases del régimen local. Comentarios, concordancias y jurisprudencia. Adaptada a la Ley de Medidas para la Modernización del Gobierno Local, Barcelona, Bosch.

cosculluela montANeR, L. (2011), Manual de Derecho Administrativo. Parte General, Madrid, 22. a edición, civitas.

CUERDA MÁS, J. (2010), "Régimen jurídico de los concejales son adscritos", Revista CEMCl, núm. 9, págs. 17 a 19.

DE ESTEBAN, J. (1990), "El fenómeno del transfuguismo político y la jurisprudencia constitucional", REP, núm. 70, págs. 7-32. 
REALA. Nueva Época - N. 9, Abril 2018 - ISSN: 1989-8975 - DOI: 10.24965/reala.v0i9.10511 - [Págs. 110-127]

De nuevo sobre los concejales no adscritos(a propósito de la sentencia del tribunal constitucional 151/2017, de 21 de diciembre)

DE LA TORRE MARTÍNEZ, L. (2012), "El derecho de los concejales no adscritos a participar en las comisiones informativas con voz y con voto (a propósito de la Sentencia del TC 20/2011, de 14 de marzo)", en libro colectivo dirigido por E. GARCÍA DE ENTERRÍA y R. ALONSO GARCÍA, Administración y Justicia. Un análisis jurisprudencial. Liber amicorum al Prof. Tomás Ramón FERNANDEZ, tomo I, Thomson-Civitas, págs. 345-371.

DE LA TORRE MARTÍNEZ, L. (2014), "La lucha por la equiparación de los derechos en los miembros de las corporaciones locales: ¿del premio al castigo?”, Revista Española de Derecho Administrativo, núm. 163, págs. 353-386.

DE LA TORRE MARTÍNEZ, L. (2014), El estatuto jurídico de los concejales no adscritos, Fundación democracia y gobierno local, serie: debates locales 4.

DE LA TORRE MARTÍNEZ, L. (2015), "El régimen estatutario de los electos locales: ¿es norma básica estatal en sentido material y formal?", en REBOLLO PUIG, M., CARBONELL PORRAS, E., LÓPEZ BENÍTEZ, M., (2015), Régimen Jurídico Básico de las Administraciones Públicas. Libro Homenaje al Profesor Luis Cosculluela, Iustel, págs. 330-347.

DÍAZ LEMA, J. M. (coord.) (2014), Sostenibilidad financiera y Administración local. Un estudio comparado, Valencia, Tirant lo Blanch.

DÍEZ QUESADA, A. (2013), "La participación de los miembros de las corporaciones locales no adscritos en las comisiones informativas: Comentarios a la luz de la sentencia del Tribunal Constitucional 246/2012, de 20 de diciembre", Consultor de los ayuntamientos y de los juzgados, núm. 24, págs. 7-2.391.

DÍEZ SÁNCHEZ, J. J. (coord.) (2013), La planta del Gobierno Local, Barcelona, Fundación Democracia y Gobierno Local.

DOMINGO ZEBALLOS, M. J. (coord.) (2014), Reforma del Régimen Local. La Ley de Racionalización y Sostenibilidad de la Administración Local: veintitrés estudios, Navarra, Thomson Reuters Aranzadi, Cizur Menor.

DOMINGO ZEBALLOS, M. J. (coord.) (2005), Comentarios a la Ley Básica de Régimen Local, Ley 7/1985, de 2 de abril, Reguladora de las Bases del Régimen Local, segunda edición, Thomson-civitas.

- El pacto local. Medidas para el desarrollo del gobierno local (1999), MAP y FEMP, pág. 102 y ss.

FERNÁNDEZ HERNÁNDEZ, O. M. (2013), "El concejal no adscrito. Evolución normativa y jurisprudencial”, Consultor de los ayuntamientos y de los juzgados, núm. 4, págs. 370-379;

FERNÁNDEZ-CORREDOR SÁNCHEZ-DIEZMA, J. (2008), "Administración local. Concejales no adscritos", CEFLegal: revista práctica de derecho. Comentarios y casos prácticos, núm. 87, págs. 125-133.

GALÁN GALÁN, A. (2004), El reglamento orgánico local, Madrid, MAP, pág. 59 y ss. BALLESTEROS FERNÁNDEZ, A. (2006), "Manual de Administración Local", 5. ${ }^{a}$ edición, Madrid, La Ley El Consultor, pág. 136 y ss.

GARCÍA DE ENTERRÍA, E. y FERNÁNDEZ RODRÍGUEZ, T. R. (2011), Curso de Derecho Administrativo, I y II, 15. ${ }^{a}$ edición, civitas.

GARCÍA GARCÍA, E. (2011), "Grupos políticos municipales: constitución y modificaciones. Concejales no adscritos", Consultor de los ayuntamientos y de los juzgados, núm. 10, págs. 1.265-1.281.

GARCÍA ROCA, J. (1998), Cargos públicos representativos. Un estudio del art. 23.2 de la Constitución, Aranzadi, pág. 79.

GONZÁLEZ DEL TESO, T. (2005), "Transfuguismo y concejales no adscritos (A propósito de la reforma de la LBRL por la Ley 57/2003)", Justicia Administrativa, núm. 27, pág. 38.

GONZÁLEZ DEL TESO, T. (2005), "Transfuguismo y concejales no adscritos (A propósito de la reforma de la LBRL por la Ley 57/2003)”, Justicia Administrativa, núm. 27, págs. 52 y 53.

- Informe sobre el gobierno local (1992), Madrid, MAP, págs. 305, 307 y 320.

JIMÉNEZ ASENSIO, R. (2004), "Ley de Modernización y Régimen Local: una perspectiva constitucional”, La Ley de Modernización del Gobierno Local, Estudis 17, Fundacó Carles Pi i Sunyer d'estudis autonomics i locals, pág. 282 y ss.

JIMÉNEZ-BLANCO CARRILLO DE ALBORNOZ, A. (1991), "Garantías institucionales y derechos fundamentales en la Constitución”, en MARTíN RETORTILLO BAQUER, S. (coord.) (1991), Estudios sobre la Constitución española: Homenaje al Profesor Eduardo García de Enterría, vol. 2 (Derechos y deberes fundamentales), págs. 635-650.

LÓPEZ FERNÁNDEZ, F. J. (2011), "Los grupos políticos y las comisiones informativas de las Entidades locales: tratamiento práctico y jurisprudencial”, Jornada sobre Constitución de nuevas Corporaciones Locales, Cádiz, Cosital.

MARTI DEL MORAL, A. (2012), "La constitucionalización del principio de estabilidad presupuestaria", en COSCULLUELA MONTANER, L.; MEDINA ALCOZ, L.; HERNANDO RYDINGS, M. y CARBONELL PORRAS, E. (dir.) (2012), Crisis económica y reforma del régimen local, Thomson-Reuters, págs. 271-292.

MARTÍN NÚÑEZ, E. (1996), El régimen constitucional del cargo público representativo, Barcelona, CEDECS, págs. 68 y 69.

MARTÍN REBOLLO, L. y ALEGRE ÁVILA, J. M. (2017), "Las competencias locales en la STC 41/2016, de 3 de marzo", en PAREJO ALFONSO, L. y VIDA FERNÁNDEZ, J. (2017), Los retos del Estado y la Administración en el siglo XXI. Libro homenaje al profesor Tomás de la Quadra-Salcedo Fernández del Castillo, Valencia, Tirant lo Blanch, pág. 2.015 y ss.

MEDINA GUERRERO, M. (2014), La reforma del régimen local, Valencia, Tirant lo Blanch. 
REALA. Nueva Época - N. 9, Abril 2018 - ISSN: 1989-8975 - DOI: 10.24965/reala.v0i9.10511 - [Págs. 110-127]

De nuevo sobre los concejales no adscritos(a propósito de la sentencia del tribunal constitucional 151/2017, de 21 de diciembre)

Lourdes de la Torre Martínez

MERINO ESTRADA, V. (2016), “¿Qué fue de la reforma local?”, Revista de Estudios Locales, núm. 190, págs. 18-10.

MUÑOZ MACHADO, S. (2011), Tratado de Derecho municipal, edición 3. a, lustel.

MURILLO DE LA CUEVA, P. L. (1992), "Problemas constitucionales de la representación política”, Debate Abierto, núm. 7 , pág. 142 y ss.

NAVARRO MENÉNDEZ, J. I. (2000), “Patología del transfuguismo político. Grandes males, pero ¿buenos remedios?”, RCG, núm. 49, págs. 41 a 45 .

NIETO-GUERREO, A. M. (2001), Los Entes Locales Municipales. Entre la política y la Administración, Madrid, INAP.

NIETO-GUERREO, A. M. (2004), Estudios para la reforma de la Administración Pública, Madrid, INAP, págs. 530 y ss.

NOGUERA MARTÍNEZ, D. (2011), "El ámbito de aplicación del estatuto legal de los representantes locales no adscritos", Anuario de Derecho Municipal, núm. 5, págs. 63-96.

PAREJO ALFONSO, L. (2004), "Una visión sobre el gobierno local”, Anuario del Gobierno Local 2004, El Gobierno local en la reforma del Estado de las autonomías, Fundación Democracia y Gobierno Local, pág. 67.

PIZARRO NEVADO, R. (2016), "Disposiciones generales, principios de actuación y funcionamiento del sector público", en GOSÁLBEZ PEQUEÑO, H. (dir.), El nuevo régimen jurídico del sector público, Madrid, Wolters Kluwer, pág. 137 y ss.

PIZARRO NEVADO, R. (2017), "Significación y claves de la Ley de Régimen Jurídico del Sector Público", Revista Gallega de Administración Pública, núm. 53, pág. 327 y ss.

PRESNO LINERA, M. A. (1998), "La superación del transfuguismo político en las corporaciones locales como exigencia de una representatividad democrática", REALA, núm. 277, pág. 120.

QUINTANA LÓPEZ, T. (dir.) y CASARES MARCOS, A. B. (coord.) (2014), La reforma del régimen local, Valencia, Tirant lo Blanch.

REBOLLO PUIG, M. e IZQUIERDO CARRASCO, M. (2006), Comentarios a la Ley Reguladora de las Bases del Régimen local, tirant lo Blanch.

REINOSO CARREIRO, A. (2007), "La moción de censura y la realidad del transfuguismo. Los miembros de las Corporaciones Locales «no adscritos»", Consultor de los ayuntamientos y de los juzgados, núm. 2, pág. 231.

RODRÍGUEZ ÁLVAREZ, J. M. (2004), "Génesis y directrices de la Ley 57/2003, de 16 de diciembre, de Medidas para la Modernización del Gobierno Local”, La Ley de Modernización del Gobierno Local, Estudis 17, Fundacó Carles $\mathrm{Pi}$ i Sunyer d'estudis autonomics i locals, pág. 32.

RODRíGUEZ ARANA, J. (dir.) y CALVO CHARRO, M. (coord.) (2002), La Administración Pública española, INAP, pág. 402.

RODRÍGUEZ ARANA, J. y SARMIENTO ACOSTA, M. J. (2014), Comentarios a la Ley 27/2013, de 27 de diciembre, de Racionalización y Sostenibilidad de la Administración local, Granada, Comares.

SÁNCHEZ MORÓN, M. (2004), "Balance de la reforma legal sobre el régimen de los «municipios de gran población»", Anuario del Gobierno Local, El Gobierno local en la reforma del Estado de las autonomías, Fundación Democracia y Gobierno Local, pág. 48.

SANTAMARÍA PASTOR, J. A. (coord.) (2014), La reforma de 2013 del régimen local español, Fundación Democracia y Gobierno Local.

VANACLOCHA BELVER, F. J. (1999), "Los fenómenos del transfuguismo en la nueva política local”, El desarrollo del gobierno local (una aproximación doctrinal), serie Administración General, Madrid, Colección Informes y Documentación, pág. 199 y ss.

VANDELLI, L. (1997), "Tendencias del Derecho Administrativo en Italia”, Documentación Administrativa, núm. 248-249, pág. 15

VILLALBA PÉREZ, F. (2006), "El estatuto de los cargos representativos locales en las reformas del Régimen local", Revista de Estudios Locales, número extraordinario, pág. 59 y ss.

ZAFRA VÍCTOR, M. (2004), "Reflexiones sobre el gobierno local", Anuario del Gobierno Local 2004, El Gobierno local en la reforma del Estado de las autonomías, Fundación Democracia y Gobierno Local, págs. 106-113. 